Archimer, archive institutionnelle de l'Ifremer August-October 2009, Volume 62, Issues 2-3, Pages http://www.ifremer.fr/docelec/ 49-61

http://dx.doi.org/10.1016/j.seares.2009.02.007

(c) 2009 Elsevier B.V. All rights reserved.

\title{
Applying Dynamic Energy Budget (DEB) theory to simulate growth and bio-energetics of blue mussels under low seston conditions
}

\author{
R. Rosland ${ }^{a,{ }^{*}}, \varnothing$. Strand $^{b}$, M. Alunno-Bruscia ${ }^{c}, C$. Bacher $^{d}$ and T. Strohmeier ${ }^{b}$ \\ a Department of Biology, University of Bergen, Postbox 7800, 5020 Bergen, Norway \\ ${ }^{b}$ Institute of Marine Research, Postbox 1870 Nordnes, 5817 Bergen, Norway \\ c Ifremer, Station Expérimentale d'Argenton, 11 Presqu'île du Vivier, 29840 Argenton-en-Landunvez, France \\ ${ }^{\mathrm{d}}$ Ifremer, Centre de Brest, B.P. 70, Z.I. Pointe du Diable, 29280 Plouzané, France \\ *: Corresponding author : R. Rosland, email address : Rune.Rosland@bio.uib.no
}

\begin{abstract}
:
A Dynamic Energy Budget (DEB) model for simulation of growth and bioenergetics of blue mussels (Mytilus edulis) has been tested in three low seston sites in southern Norway. The observations comprise four datasets from laboratory experiments (physiological and biometrical mussel data) and three datasets from in situ growth experiments (biometrical mussel data). Additional in situ data from commercial farms in southern Norway were used for estimation of biometrical relationships in the mussels. Three DEB parameters (shape coefficient, half saturation coefficient, and somatic maintenance rate coefficient) were estimated from experimental data, and the estimated parameters were complemented with parameter values from literature to establish a basic parameter set. Model simulations based on the basic parameter set and site specific environmental forcing matched fairly well with observations, but the model was not successful in simulating growth at the extreme low seston regimes in the laboratory experiments in which the long period of negative growth caused negative reproductive mass. Sensitivity analysis indicated that the model was moderately sensitive to changes in the parameter and initial conditions. The results show the robust properties of the DEB model as it manages to simulate mussel growth in several independent datasets from a common basic parameter set. However, the results also demonstrate limitations of $\mathrm{Chl}$ a as a food proxy for blue mussels and limitations of the DEB model to simulate long term starvation. Future work should aim at establishing better food proxies and improving the model formulations of the processes involved in food ingestion and assimilation. The current DEB model should also be elaborated to allow shrinking in the structural tissue in order to produce more realistic growth simulations during long periods of starvation.
\end{abstract}

Keywords: mussel culture; Mytilus edulis; DEB theory; modelling; low seston 


\section{Introduction}

Individual bivalve growth has been modelled using a range of energetic models, from empirical based net-production models (Ross and Nisbet, 1990; Smaal and Widdows, 1994; Barillé et al., 1997; Grant and Bacher, 1998; Scholten and Smaal, 1998; Ren and Ross, 2001; Hawkins et al., 2002; Gangnery et al., 2003) to the recent use of more mechanistic models based on the Dynamic Energy Budget (DEB) theory (Van Haren and Kooijman, 1993; Ren and Ross, 2005; Pouvreau et al., 2006; Ren and Schiel, 2008). Most of this work is related to the need for tools to understand ecological interactions and processes of relevance for estimating carrying capacity in shellfish culture. The increasing interest to use the DEB model to study bio-energetics and growth of several bivalve species has support in the successful application to simulate growth and reproduction in the Pacific oyster, Crassostrea gigas (Pouvreau et al., 2006; Bacher and Gangnery, 2006; Bourlès et al., subm). For other bivalve species most model parameters have so far only been estimated using literature data from independent studies (Van der Veer et al., 2006), whereas it is regarded preferably to estimate the various parameters from experiments in which physiological processes are determined simultaneously under varying feeding conditions and food intake (Kooijman, 2000). The current development and implementation of a DEB model on the mussel Mytilus edulis addresses the requirements of data from contrasted environmental conditions in order to test, to validate and to refine the estimated parameter set.

The mussel $M$. edulis naturally occurs in a wide range of environmental conditions and culture is carried out in temperate waters around the world. Norwegian fjords and coastal waters are considered as low seston environments (Strohmeier et al., 2008) compared to sites where most studies on mussel feeding and growth have been carried out (Smaal and Vonck, 1997; Grant and Bacher, 1998; Pitcher and Calder, 1998; Figueiras et al., 2002; Hawkins et al., 2002; Van der Veer et al., 2006). Phytoplankton constitutes the major carbon component of the seston (Erga, 1989a; Erga et al., 2005), and the concentration of Chlorophyll a ( $\mathrm{Chl} \mathrm{a}$ ) along the Norwegian coast is generally less than 2 $\mu \mathrm{g} \mathrm{L}^{-1}$ (Erga, 1989; Frette et al., 2004; Aure et al., 2007a) due to nutrient limitation (Paasche and Erga, 1988; Erga et al., 2005). Strohmeier et al. (subm.) studied feeding responses by the mussel $M$. edulis in a very low seston environment, consisting of four feeding treatments of ambient and diluted natural seston (range of mean; 0.01 to $0.88 \mu \mathrm{g}$ Chl $\mathrm{a} \mathrm{L} \mathrm{L}^{-1}$ ). Low seston environments do not only occur under natural oligotrophic conditions, but may also take place where high bivalve (culture) densities cause seston depletion (Blanco et al., 1996; Fréchette et. al, 1989; Strohmeier et al., 2005, 2008). Bivalve culture in such conditions may suffer low growth or reduction of soft tissue due to reduced feeding and negative net energy balance.

This paper presents the results from a DEB mussel model which has been applied to three sites in Norway. The model is designed for simulating growth and reproduction of blue mussels using the DEB approach (Kooijman, 1986; 2000). The mussel model was originally developed for oysters (Pouvreau et al., 2006 ; Bacher and Gangnery, 2006), but was later modified to model mussels by adapting it to parameters presented in Van der Veer et al. (2006) and Mazurié et al. (in prep.). The datasets of this model study include four time series from laboratory experiments in which physiological processes of $M$. edulis was determined simultaneously over a period of several months and under low seston conditions (Strohmeier et al., subm.), and three time series from in situ growth 
experiments at three sites in southern Norway. Besides biometric data on M. edulis, all the datasets included time series on seawater temperatures and $\mathrm{Chl}$ a concentrations.

The objectives of this study are to: 1) estimate parameters of the DEB model for $M$. edulis in low seston environments in Norway, 2) validate the model by comparing simulations with growth data on mussels from different sites in southern Norway, and 3) assess the quality of the estimated DEB parameters and the model robustness to changes in parameter values, initial conditions and environmental forcing.

\section{Material and methods}

This study was conducted in three stages:

1. Estimate three DEB parameters (shape, half-saturation and somatic maintenance rate) from experimental datasets and establish a new low seston parameter set

2. Conduct model simulations using the established parameter set and validate model against the seven datasets

3. Assess the quality of the estimated parameters and test model robustness

Each of these stages is described more thoroughly below after a brief presentation of the datasets and the DEB-mussel model.

\subsection{Datasets}

The data are obtained from laboratory and in situ experiments, and from commercial mussel farms in southern Norway (Fig. 1). The experimental datasets 1-4 from Austevoll research station include time series on physiological, biometrical and environmental data, which were used to estimate DEB parameters (see sections 2.3.1-2.3.3) and to force the model. The datasets from the sites in Toskasundet (dataset 5), Austevoll (dataset 6) and Flødevigen (dataset 7) include time series on biometrical and environmental data. The environmental forcing data on $\mathrm{Chl}$ a and sea water temperature for the datasets 1-7 are displayed in Fig. 2. Chl a was selected as a proxy for food concentration because this was reported to be the dominating carbon component of the seston in Norwegian waters (Erga, 1989; Erga et al., 2005) and was considered to be the most conventional food proxy when the experiments were initiated. Besides, Chl a was the only common food proxy available for all the seven datasets. Some initial attempts to estimate and calibrate the ingestion parameters on POC concentrations were done, but this alternative was not followed up here since there seemed to be little correspondence between POC concentrations and mussel growth.

The estimation of the wet-dry mass ratio and the shell length-volume relationship were based on data collected at commercial mussel farms (Fig. 1) at Frønningen in Sognefjorden (Duinker et al., 2007), at Fyksesund in Hardangerfjorden and at Forsand in Lysefjorden (unpublished data).

\subsubsection{The laboratory experiments (datasets 1-4)}

The datasets 1-4 are from experiments conducted at Austevoll research station, from August 2006 to April 2007. A cohort of mussels ( $n=350 ; 52-66 \mathrm{~mm}$ shell length) collected from a commercial long-line farm, were equally distributed among four indoor holding tanks (width $=1.05 \mathrm{~m}$, length $=1.92 \mathrm{~m}$ and height $=0.71 \mathrm{~m}$ ). They were exposed to four natural seston treatments, hereafter referred as datasets 1-4, consisting of ambient seawater from 5 meter depth and diluted concentrations using water from 160 
meter depth. Temperature and salinity were measured daily in each holding tank. Chl a was determined by filtering seston $\left(500 \mathrm{~cm}^{3}\right.$ ) onto a $1.2 \mu \mathrm{m}$ filter (Whatman GF/C), and analyzed according to Strickland and Parson (1972).

The four treatments ranged in mean concentration from 0.15 to $0.43 \mathrm{mg} \mathrm{L}^{-1}$ of suspended particulate matter (SPM) and 0.01 to $0.88 \mu \mathrm{g} \mathrm{L-1} \mathrm{Chl} \mathrm{a} \mathrm{(Strohmeier} \mathrm{et} \mathrm{al.,}$ subm.). The mean particulate organic content ranged from 68 to $75 \%$. The experimental time series contains fortnightly data on individual clearance rate, monthly data on oxygen consumption and ammonia excretion at four occasions as described in Strohmeier et al. (subm.). Clearance rate measurements were conducted by transferring 18 mussels from each holding tank to individual flow-through chambers, similar in design and method used by Palmer and William (1980).

\subsubsection{The in situ experiments (datasets 5-7)}

The three datasets 5-7 are from in situ growth experiments in which mussels were grown in suspended cultures at Toskasundet from August 2006 to April 2007, at Austevoll from February to December 2007 and at Flødevigen from March to November 2007. At Austevoll and Flødevigen the mussels were initially socked on ropes at densities of about 150-200 mussels $\mathrm{m}^{-1}$, and ropes of 1-2 $\mathrm{m}$ length were held at about $5 \mathrm{~m}$ and 1-3 m depth, respectively. At Toskasundet the mussels were held in stacked trays $(60 \times 60 \mathrm{x}$ 10 (height) cm) mounted about $2 \mathrm{~m}$ above the bottom of about $14 \mathrm{~m}$ depth. The mussels were grown at a density of 10-20 mussels per tray. Mussel data were sampled at a monthly frequency and was carried out by removing all mussels from a portion of the rope, holding about 30-50 individuals, and 10-20 mussels from each tray. Sampled mussels were dissected, dried at $60^{\circ} \mathrm{C}$ for 48 hours, weighed for determination of dry tissue mass and measured for shell length $(L, \mathrm{~cm}$, anteroposterior axis). The initial mean shell length of the experimental mussels were about $5.8 \mathrm{~cm}$ for Toskasundet, $3.6 \mathrm{~cm}$ for Austevoll and $2.3 \mathrm{~cm}$ for Flødevigen, reflecting the difference in mussel age composition among the sites.

At Austevoll (5 m depth) and Toskasundet temperature and fluorescence measurements were simultaneously measured at $5 \mathrm{~min}$. intervals using a STD/CTD 204 instrument (SAIV A/S, Norway). Fluorescence units were converted to $\mathrm{Chl}$ a concentration using a calibration obtained from analysis of water samples (as in 2.1.1), and according to the equation: $\mu \mathrm{g} \mathrm{Chl} \mathrm{a} \mathrm{L}^{-1}=(0.84$.fluorescence $)-0.12 ;\left(r^{2}=0.93, n=33\right)$.

At Flødevigen seawater temperature at $1 \mathrm{~m}$ depth was measured with a thermometer. Water samples integrated between surface and $3 \mathrm{~m}$ depth were analysed for $\mathrm{Chl} \mathrm{a}$ according to method described above in section 2.1.1.

\subsection{The DEB model for blue mussels}

The current model is based on DEB theory (Kooijman, 1986; 2000) and originates from a growth model for $M$. edulis (Van Haren and Kooijman, 1993). The mathematical equations are similar to those presented in Pouvreau et al. (2006) and Van der Meer (2006), while most of the parameter values are from Van der Veer et al. (2006) and Mazurié et al. (in prep.). The following text applies the DEB symbols and notations described (Kooijman, 2000) where square brackets [] denote quantities expressed as per unit structural volume, while braces \{\} denote quantities expressed as per unit surface-area of the structural volume. All rates, i.e. dimension per time, have dots above their symbol. 
The DEB model is based on the assumption that assimilated energy first enters a reserve compartment. A fixed fraction $K$ of the energy flux from the reserves is then utilised for growth and somatic maintenance, but maintenance is given first priority under energy limitation. Remaining energy $(1-K)$ is spent on maturation and reproduction in juveniles and adults, respectively, including maintenance of these body parts. The energy ingestion rate $\left(\mathrm{J} \mathrm{d}^{-1}\right)$ is proportional to the surface area of the structural body volume $V^{2 / 3}$ :

$$
\&_{X}=\left\{\&_{x m}\right\} f V^{2 / 3} \text { with } f=\frac{X}{X+X_{K}}
$$

where $\{d m\}$ is the maximum ingestion rate per unit surface area $\left(\mathrm{J} \mathrm{cm}^{-2} \mathrm{~d}^{-1}\right)$. The dimensionless function $f$ ranges from 0 to 1 and scales ingestion rate in relation to food concentration $(X)$ according to a Holling II functional response. $X_{K}$ is the half-saturation coefficient ( $\mu \mathrm{g} \mathrm{Chl} \mathrm{a} \mathrm{L}^{-1}$ ) at which the ingestion rate is half the maximum. The assimilation rate $\left(\mathrm{J} \mathrm{d}^{-1}\right)$ is:

$$
\mathbb{R}_{A}=\left\{\mathbb{A}_{A m}\right\} f V^{2 / 3}
$$

where $\{\& \mathrm{am}\}$ is the maximum surface-area-specific assimilation rate $\left(\mathrm{J} \mathrm{cm}^{-2} \mathrm{~d}^{-1}\right)$. The value depends on diet and the ratio $\left\{\&_{A m}\right\} /\left\{\&_{X m}\right\}$ gives the conversion efficiency from ingested food to assimilated energy, known as the assimilation efficiency ( $\kappa_{A}$ in the DEB terminology). The instantaneous change in reserves $\left(\mathrm{J} \mathrm{d}^{-1}\right)$ is:

$$
\frac{d E}{d t}=\& \&_{A}-\&
$$

where $\left(\mathrm{J} \mathrm{d}^{-1}\right)$ is the utilisation rate, i.e. energy (fixed and dissipated) consumed by the body tissues. Maintenance rate $\&_{M}$ is proportional to structural volume $V$, so that $\&_{M}=\left[\&_{M}\right] V$, where $\left[\&_{M}\right]$ represents the volume specific maintenance rate $\left(\mathrm{J} \mathrm{cm}^{-3}\right.$ $\left.\mathrm{d}^{-1}\right)$. Thus structural body volume $V\left(\mathrm{~cm}^{3}\right)$ changes according to:

$$
\frac{d V}{d t}=\left(\kappa \&-\& \&_{M}\right) /\left[E_{G}\right]
$$

where $\left[E_{G}\right]$ is the volume-specific costs of structural growth $\left(\mathrm{J} \mathrm{cm}^{-3}\right)$. Kooijman (2000) showed that fixed and dissipated energy consumed by the body tissues can be written as:

$$
\not E=\frac{[E]}{\left[E_{G}\right]+\kappa[E]}\left(\frac{\left[E_{G}\right]\left\{\& \Delta_{m}\right\} V^{2 / 3}}{\left[E_{m}\right]}+\left[\&{ }_{1}\right] V\right)
$$


where $[E]$ is energy density $(=E / V)$, and $\left[E_{m}\right]$ represent the maximum energy density of the reserve compartment (i.e. $[E]$ ranges between 0 and $\left[E_{m}\right]$ ). The remaining fraction $(1-k)$ of utilised energy is allocated to maturity maintenance and maturity in embryos and juveniles, or reproduction (i.e. gamete production and spawning) in adults. The dynamics of energy $\left(\mathrm{J} \mathrm{d}^{-1}\right)$ allocated to the reproductive buffer $\left(E_{R}\right)$ are:

$$
\frac{d E_{R}}{d t}=(1-\kappa) \&-\left(\frac{1-\kappa}{\kappa}\right) \cdot \min \left(V_{P}, V\right) \cdot\left[\&_{M}\right]
$$

where $V_{P}$ is the threshold size (Kooiiman, 2000) of the structural volume where energy shifts from maturity development to gamete production.

Spawning is forced on the mussels, and given that the reproductive buffer $\left(E_{R}\right)$ is greater than zero the mussels spawn at dates corresponding to spawning events in the observed datasets. According to Pouvreau et al. (2006) it is assumed that the reproductive compartment is totally emptied during spawning.

In case reserves are too low to support maintenance costs, then energy can be withdrawn from the reproductive buffer through lysis of gonadic tissue. In this situation the dynamics of the reproductive buffer becomes:

$$
\frac{d E_{R}}{d t}=\kappa \& \&_{C} \mid \kappa \& \&_{C}-\&_{M}<0
$$

Under prolonged starvation the reproductive buffer may eventually become negative. This is not realistic, but it simply means that the model is running out of its validity range.

All the physiological rates in the model depend on body temperature (i.e. surrounding water temperature for mussels) and this relationship is given by the Arrhenius function (Kooijman, 2000). The reference temperature $\left(T_{1}\right.$, Table 1$)$ for the physiological parameters is $20^{\circ} \mathrm{C}$.

Assuming that mussels grow isomorphically, then the proportionality coefficient ( $\delta_{v}$, i.e. the shape parameter in DEB terminology) between shell length $L(\mathrm{~cm})$ and structural volume $V\left(\mathrm{~cm}^{3}\right)$ is defined by:

$\delta_{V}=\frac{V^{1 / 3}}{L}$

The body volume can be estimated from wet mass data by assuming that the density of the structural volume equals $1 \mathrm{~g} \mathrm{~cm}^{-3}$.

\subsection{The basic parameter set of the model}

Three DEB parameters: the shape coefficient $\left(\delta_{V}\right)$, the half-saturation coefficient $\left(X_{K}\right)$ for food ingestion, and the somatic maintenance rate $\left(\left[\beta_{M}\right]\right)$ were estimated from the experimental datasets according to the procedures below. The estimated parameters were complemented by parameter values from the literature (van der Veer et al., 2006; Mazurié et al. in prep.) to establish a low seston parameter set, hereafter referred to as the basic parameter set, which was used for the simulations of datasets 1-7 in the validation procedure. 


\subsubsection{The shape coefficient}

The shape coefficient $\left(\delta_{V}\right)$ in equation (8) was estimated from data on shell length $L(\mathrm{~cm})$ and dry flesh mass $M(\mathrm{~g})$. Dry flesh mass was converted to wet flesh mass $\left(M_{w}\right)$ by a dry-to-wet-mass conversion factor which was estimated to $0.2 \mathrm{~g} \mathrm{M} \mathrm{g}^{-1} M_{w}$ from observed data. Estimated wet mass was then used to substitute structural volume $V\left(\mathrm{~cm}^{3}\right)$ in equation (8).

Since observed flesh mass of mussels grown in a natural cycle includes gonads, structure and reserves (i.e. not only structure) this value cannot be applied directly to estimate $\delta$. The shape parameter was estimated by two approaches.

The first approach used data on shell length and dry flesh mass from Flødevigen, where mussels had been kept at extreme low seston concentrations (water from $75 \mathrm{~m}$ depth) for three weeks in July. Based on the assumption that flesh mass mainly constituted structure after the starvation period, the shape parameter $\left(\delta_{V}\right)$ was estimated by linear regression of equation (8), i.e. $V^{1 / 3}=\delta_{V} \cdot L$.

The second approach applied pooled data on shell length and dry flesh mass of adult mussels grown under natural conditions, e. g. upper part of water column ( $<10 \mathrm{~m}$ depth) from the sites Frønningen, Fyksesund, Austevoll, Lysefjorden, Flødevigen (see Fig. 1). A length-volume curve based on equation (8) was fitted by tuning the shape coefficient $\left(\delta_{V}\right)$ to get $5 \%$ of the observed mussel masses below the fitted curve. The rationale was that a curve for structural mass should ideally lie below the observed masses, which in addition to structure also include reserves and reproductive mass. However, by accounting for unknown variability in the mass composition and measurement errors, the shape parameter was tuned in order to get $5 \%$ of the observed flesh mass below the fitted curve.

\subsubsection{The half-saturation coefficient}

The energy ingestion rate $\&_{x}\left(\mathrm{~J} \mathrm{~d}^{-1}\right)$ is given in equation (1). At low food concentrations (i. e. no pseudo-faeces production) the filtration rate $\left(F_{r}, \mathrm{~J} \mathrm{~d}^{-1}\right)$, which is the product of

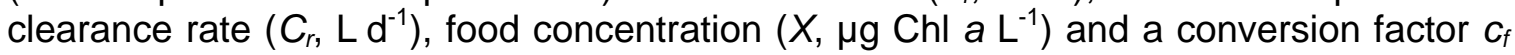
$\left(\mathrm{J}^{\mathrm{g}} \mathrm{g}^{-1} \mathrm{Chl}\right.$ a): $F_{r}=C_{r} \cdot X \cdot c_{f}$ equals ingestion rate. Rearranging equation (1) by substituting the energy ingestion rate $\&_{x}$ with the filtration rate $\left(F_{r}\right)$, and removing $X$ from the denominator (by assuming $X \ll X_{K}$ ) allows us to express the half-saturation coefficient as:

$$
X_{K}=\frac{\left\{\&_{X m}\right\}}{C_{r}} V^{2 / 3} c_{f}^{-1}
$$

Clearance rates $\left(C_{r}\right)$ were estimated from the experimental datasets 1-4 (Strohmeier at al., subm.). The half-saturation coefficient estimated in equation (9) was converted from energy units $\left(\mathrm{J} \mathrm{d}^{-1}\right)$ to $\mathrm{Chl}$ a $\left(\mu \mathrm{g} \mathrm{L}^{-1}\right)$ by a conversion factor $c_{f}\left(0.419 \mathrm{~J}^{-1} \mathrm{Chl}\right.$ a) which was obtained from values on energy per unit Carbon $\left(11.4 \mathrm{cal} \mathrm{mg}^{-1} \mathrm{C}\right)$ in phytoplankton (Platt and Irwin, 1973), conversion from Calories to Joule (4.189 Joule/Cal) and a Carbon:Chl a ratio of $50 \mathrm{mg} \mathrm{C} \mathrm{mg}^{-1} \mathrm{Chl} \mathrm{a}$. 


\subsubsection{The somatic maintenance rate}

The approach applied here was similar to that of Van der Veer et al. (2006) and it assumes that respiration mainly reflects maintenance metabolism of the mussels during starvation. Oxygen consumption rates $\left(\mathrm{O}_{c}, \mathrm{mg} \mathrm{O}_{2} \mathrm{~d}^{-1}\right)$ measured for individual mussels were used to estimate the volume-specific maintenance rate $\left(\left[\&_{M}\right], \mathrm{J} \mathrm{cm}^{-3} \mathrm{~d}^{-1}\right.$ ). Only data from the period between November 2006 and January 2007, when food concentrations were low in all experiments (Fig. 2), were applied. The parameter for somatic maintenance costs $\left(\left[\&_{M}\right]\right)$ were calculated as:

$\left[\&_{M}\right]=\kappa \eta O_{c} V^{-1}$

where $\kappa$ is the fraction allocated to somatic growth, $\eta$ is a constant $\left(14.3 \mathrm{~J} \mathrm{mg}^{-1} \mathrm{O}_{2}\right)$ for converting oxygen to energy equivalents (Gnaiger and Forstner, 1983), and $V$ is the structural volume $\left(\mathrm{cm}^{3}\right)$ of the mussels which was calculated from equation (8) using the shape parameter $(\delta v)$ estimated from the observations.

\subsection{Model simulation and validation procedures}

The model was run using the basic parameter set described under section 2.3 and listed in Table 1. The model was forced with observed Chl a concentrations and water temperatures (Fig. 2) for each of the datasets 1-7, and the mussels were initialised at dry flesh masses and shell lengths corresponding to the average mussels at the start of each of the datasets (see 2.1). The model was run over the same time period as the datasets. The model was validated by comparing simulated and observed shell length $L$ $(\mathrm{cm})$ and dry flesh mass $M(\mathrm{~g})$. The deviation $(F)$ between simulations and observations were calculated for each dataset according to:

$$
F=\frac{100}{2 T}\left(\sum_{t=1}^{T} \frac{\left|L_{m}(t)-L_{o}(t)\right|}{L_{o}(t)}+\sum_{t=1}^{T} \frac{\left|M_{m}(t)-M_{o}(t)\right|}{M_{o}(t)}\right)
$$

where $t$ is the time index and $T$ is the total number of observations in each dataset.

\subsection{Testing the quality of estimated parameter values}

The quality of the estimated values of the half-saturation coefficient $\left(X_{K}\right)$ and the somatic maintenance rate $\left(\left[\&_{M}\right]\right)$ was tested by comparison with parameter values obtained by auto-calibration. A non-linear optimisation method (Nelder-Mead) was applied in the auto-calibration, using shell length and dry flesh mass as the optimisation criteria. The auto-calibration searched iteratively for the parameter values that minimised the difference $(F)$ according to equation (11).

\subsection{Testing model robustness to changes in parameter values, initial conditions and environmental forcing variable}

The model robustness (S) with respect to parameter values was calculated as the deviation between simulated shell length $(L)$ and dry flesh mass $(M)$, from the basic parameter set (see section 2.3), and simulated shell lengths and dry flesh mass $\left(L_{s d}\right.$, $\left.M_{s d}\right)$ from basic parameters \pm the standard deviation of the parameter estimates $\left(p_{s d}\right)$ : 


$$
S=\frac{1}{2 T}\left(\sum_{t=1}^{T} \frac{\left|L_{s d}(t)-L(t)\right|}{L(t)}+\sum_{t=1}^{T} \frac{\left|M_{s d}(t)-M(t)\right|}{M(t)}\right) / \frac{\left|p_{s d}-p\right|}{p}
$$

This sensitivity measure is adapted from Wei et al. (2004), but only absolute values are used here since the measure comprises two variables ( $L$ and $M)$. The sensitivity to the parameters was defined as the relative change in simulated variables divided by the relative change of the respective parameter. Wei et al. (2004) classified sensitivity as insensitive $(\mathrm{S}<0.1)$, sensitive $(0.1<\mathrm{S}<0.4)$ and more sensitive $(\mathrm{S}>0.4)$.

The initial division of body mass between structure, reserves and reproduction was done by first calculating the structural mass from observed shell length, using equation (8), and converting volume to dry flesh mass. Then observed flesh mass was then subtracted the estimated structural mass, and the rest fraction was equally split between reproductive and reserve compartments. The effect of the initial mass distribution between reproduction and reserves was tested in two simulations where the mussels were initialised with structure and: a) reserves only and b) reproduction only.

The effect of $\mathrm{Chl}$ a concentration on the simulated growth was tested for dataset 7 (Flødevigen). Observed $\mathrm{Chl}$ a concentrations were multiplied by a constant factor that was calibrated to obtain the best fit (i.e. least deviation according to equation (11)) between simulated and observed shell lengths and dry flesh mass.

\section{Results}

\subsection{Parameter estimations from experimental data}

The shape parameter estimated by regression of data on starved mussels $(n=99)$ from Flødevigen was: $\delta=0.231 \pm 0.003$, with a correlation coefficient of 0.986 . The alterative approach where the shape parameter was tuned to fit the length-weight curve from equation (8) to cut the lower $5 \%$ of a pooled mussel dataset yielded: $\delta=0.227$. The two curves are plotted with the observations in Fig. 3.

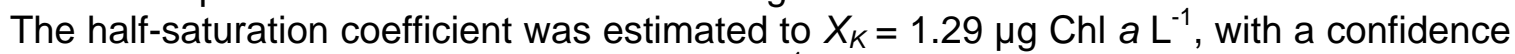

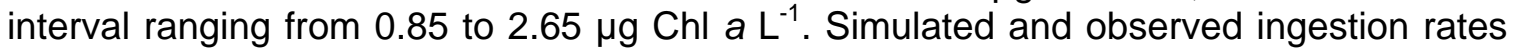
for datasets 1-3 are plotted in Fig. 4. There is a good fit between simulated and observed values for $\mathrm{Chl}$ a concentrations below $1 \mu \mathrm{g} \mathrm{Chl} \mathrm{a} \mathrm{L}^{-1}$, but the model underestimates ingestion rates at higher $\mathrm{Chl}$ a concentrations.

The maintenance rate $[\mathrm{d}]$ estimated from the experiments was $27.8 \pm 3.3 \mathrm{~J} \mathrm{~cm}^{-3} \mathrm{~d}^{-1}$. The estimated parameter values are listed in Table 1.

\subsection{Simulating mussel growth from the basic parameter set}

Simulated and observed shell lengths and dry flesh masses for datasets 1-7 are displayed in Figs 5 and 6, respectively. Simulated and observed shell lengths (i.e. structural growth) remain constant in datasets 1-4, and the simulated values are within the standard deviations of the observations for all months except February. Simulated dry flesh masses are also within observed standard deviations, except in February (dataset 1) and from February-April in dataset 4 . The model captures the seasonal 
patterns quite well, but underestimates the mass loss in datasets 1-2 and overestimates it in datasets 3-4.

The model simulation gives a fairly good representation of the observations and the seasonal growth patterns in dataset 5 (Toskasundet), although some of the simulated values are outside the observed standard deviations. The model overestimates growth in the first months and underestimates growth during the last months in Toskasundet.

Both simulated shell lengths and dry flesh masses in dataset 6 (Austevoll) fit quite well with observations, and the model captures the seasonal dynamics very well. This is not the case for dataset 7 (Flødevigen) where the model clearly underestimates mussel growth, which results in a progressively increasing mismatch between simulated and observed shell length and flesh dry mass.

Simulated reserve dynamics are displayed for all datasets in Fig. 7. The reserves increase during February-April in datasets 1-3 and 5, and in autumn in datasets 1, 5 and 6. The reserves decrease during the winter in datasets 1,2 and 5 , and during the summer period in dataset 6 . The energy reserves in dataset 7 increases steadily during the spring and summer until it drops in late autumn.

Simulated reproductive compartment dynamics are displayed for all datasets in Fig. 7. The reproductive compartment increases unless the mussels are spawning or the reserves are empty, which means that the mussels start consuming reproductive energy to support maintenance costs. Lysis of the reproductive compartment occurs in datasets 1-4 during the low food periods between November-February, and is evident as a decrease in the reproductive mass, which actually turns negative in periods. This is most pronounced in datasets 3-4 where the negative values become quite large. Lysis of the reproductive compartment also occurs between December-February in dataset 5, but reproductive mass does not become negative here.

The abrupt drops in the reproductive compartment in datasets 5-7 are due to forced spawning events corresponding to spawning dates in the observed datasets.

The deviations (see equation (11)) between simulated and observed shell lengths and dry flesh masses are listed in Table 2. Ranking the simulations according to their deviations from each dataset gives: $6<5<2<1<3<4<7$, which mean best fit with dataset 6 (Austevoll) and worst fit with dataset 7 (Flødevigen). The total deviation for all datasets pooled is $14.7 \%$.

A simulation based on parameters from literature only (i.e. omitting the parameter values estimated in this study) results in higher deviations for all datasets (Table 2). The negative values in the reproductive compartment increases in datasets 1-4, but also occur in datasets 5 and 6 with these parameter values.

\subsection{Quality of estimated parameters}

The quality of the estimated parameter values was assessed by comparison with autocalibrated parameter values (Table 3 ) for each dataset and for all datasets combined (pooled dataset). The calibrated values of the half-saturation coefficient $\left(X_{K}\right)$ lie within the standard deviation of the estimate, except for datasets 4 and 7 , which yielded much lower values. The calibrated value for the pooled dataset (all datasets combined) is very close to the estimate. 
The calibrated values of the maintenance rate [ $\left[\&_{1}\right]$ for datasets $3,5,6$, and the pooled dataset are all within the standard deviations of the estimated value, while the calibrated value for datasets 1 and 2 are slightly outside. The calibrated maintenance rates for datasets 4 and 6 are far below the estimate.

Calibration of the maximum ingestion rate $\left\{\&_{X_{m}}\right\}$ resulted in lower values for datasets 1 , 2,5 and 6, and higher values for datasets 3, 4 and 7 compared to the parameter value of the basic parameter set. Also here the calibrated values for datasets 4 and 7 were far off range of the basic parameter value. The calibrated value for the whole pooled dataset was identical to the basic parameter value.

The effects on the model performance by using calibrated versus basic parameter values are displayed in Figs $8-9$, and the model performance is quantified as the deviation between simulated and observed shell lengths and flesh dry masses according to equation (11) in Table 3 . The results show that the calibrated parameter values reduce this deviation by only up to $3.5 \%$ for datasets $1-3,5$ and 6 , while the deviation is reduced by up to $22 \%$ for datasets 4 and 7 . The parameters calibrated on the pooled dataset give similar results as the basic parameter set.

\subsection{Model robustness to changes in parameter values, initial conditions and environmental forcing}

Sensitivity to changes in parameter values were tested by increasing and decreasing the half saturation coefficient $\left(X_{K}\right)$ and the maintenance parameter [ $\left.\&_{M}\right]$ by one standard deviation from the estimates (Table 1 ). The sensitivity is calculated according to equation (12) and the results are listed in Table 4. According to the classification from Wei et al. (2004) the model is sensitive to these parameters except for datasets 2-4, which are insensitive to increasing $X_{K}$, datasets 3-4 which are very sensitive to changes in [ $\left.\&_{M}\right]$, and dataset 5 which is very sensitive to lowering the $X_{K}$. The pooled dataset is very sensitive to changes in $\left[\&_{M}\right]$.

Deviations between simulations and observations caused by initial allocation of nonstructural mass between reproductive and reserve compartments were calculated for the cases where: a) all is allocated to the reproductive compartment; and b) all is allocated to the reserve compartment; c) there is an equal division between reproduction and reserves (i.e. the basic setting). Initial condition has little effect on the overall performance of the model except for datasets 6 and 7 .

In order to test the influence of $\mathrm{Chl}$ a on the simulated growth, the $\mathrm{Chl}$ a concentrations in dataset 7 were multiplied by a constant factor to test how this could improve the fit between simulations and observations in Flødevigen. Auto-calibration according to equation (12) yielded a Chl a factor of 4.13 , which reduced the deviation from $35.5 \%$ to 13.6\%. The simulated shell lengths and flesh dry masses for dataset 6 at this Chl a level are displayed in Figure 10. 


\section{Discussion}

The results presented here show that the DEB model for mussel growth is capable of reproducing observed patterns of growth for most of the low seston sites. The fact that the model simulations used for validation were produced from a common basic parameter set, where the parameters were taken either from literature (i.e. independent data) or estimated directly from experimental data, demonstrates the robustness and generality of the DEB model. However, the validation also reveals clear deviations between simulations and observations for some datasets. This may be due to many factors, including errors in the validation data. The observed growth data are generally within the range of growth rate previously reported for mussels ( $M$. edulis) in temperate waters, except for the growth during late autumn at Flødevigen, which was substantially higher than growth observed at other sites (Mallet and Carver, 1993; Karayücel and Karayücel, 2000). The further discussion will focus on potential limitations in the DEB concepts and the way the model was implemented at the actual sites.

The non-structural mussel mass was simply split equally between reproductive and reserve compartments at the initial time step. The sensitivity test indicated that this generally had little impact on the results (Table 2) except for dataset 6 , where an early spawning event combined with slow initial growth (i.e. the reserve and reproductive compartments changed little from initial values) makes this dataset more sensitive to initial condition.

Most of the model parameters were taken from previous studies (Van der Veer et al., 2006; Mazurié et al., in prep.) except for the half-saturation coefficient $\left(X_{K}\right)$, the somatic maintenance costs $([\&])$ and the shape parameter $(\delta)$, which were estimated from the experimental datasets and included in the basic parameter set. A good fit between model simulations and observations indicates that the model parameters are set within acceptable ranges. Thus, except for datasets 4 and 7 the estimated parameter values seem adequate for the sites that were tested here. This finding was also confirmed by the auto-calibration procedure in which optimised parameter values and model simulations based on these did not differ much from the estimated parameter values (Tables 1, 2, and 3). The exceptions were datasets 4 and 7 where the auto-calibration yielded very different parameter values, apparently with little biological realism, which clearly improved the fit between simulations and observations. However, the extreme parameter values obtained by calibration of datasets 4 and 7 indicate that there are more than just parameters causing problems in these simulations.

The simulations from the basic parameter set also gave a better fit with observations than simulations from a parameter set based entirely on values from the literature (Table 2). This in combination with the calibration results consolidates the quality of the parameter values estimated here for the low seston environment.

The maintenance rate [ $\left[{ }_{1}\right]$ estimated here is slightly higher than the value reported by Van der Veer et al. (2006). The estimate of maintenance rate rests on the assumption that energy consumption is mainly due to maintenance during the starvation period. The experiments did not use filtered water and it is possible that food particles in the water could violate this assumption and raise the metabolism due to digestive processes. Besides, a long starvation period and a shift in the metabolic fuel (e.g. from fat to proteins) could also affect the estimate of maintenance rate. The O:N molar ratio of oxygen consumed to nitrogen excreted gives an indication of the proportion of protein 
catabolised relative to carbohydrates and lipids (Conover and Corner, 1968). Low values indicate protein metabolism as opposed to greater contribution of non protein sources to energy metabolism when the ratio is higher. Unpublished results from the experimental studies (Strohmeier et al. subm.) showes that the O:N ratio points to protein metabolism during winter in all the experimental treatments (datasets 1-4). In datasets 1 and 2, the $\mathrm{O}: \mathrm{N}$ ratio indicates non-protein catabolism during autumn and spring, but in experiments 3 and 4 the catabolism constitutes more proteins as time passes during the experiment. Whyte et al. (1990) also observed that protein constituted the most important energy source for oysters (Crassostrea gigas) during starvation.

It is also during the long starvation periods in datasets 1-4 the most obvious problem with model simulations occur. When the reserves are exhausted, due to long periods of energy deprivation, the model mussels start utilising reproductive mass to cover maintenance costs until the reproductive compartment eventually runs empty or turns negative. This result makes little sense in terms of mass balances, but it demonstrates a weakness of the current DEB model, which does not allow energy extraction from the structural tissue. As explained above this is what happens in the datasets 1-4 (Strohmeier et al. subm.) and has also been observed in previous studies on oysters (Whyte et al., 1990) and fresh water mussels (Downing and Downing, 1993). Downing and Downing (1993) also reported reductions in shell length during energy deprivation. Thus, the model would be more realistic if it included mechanisms for energy withdrawal from structural mass, which would also imply shrinking of the structural volume and a reduction of the maintenance cost, which is scaled to the structural volume in the DEB model. Regarding mussels this raises questions concerning how shell length responds to a shrinking structure. Currently we do not have sufficient data to construct and parameterize a model extension like this and we will not address this question further here.

The estimated half-saturation coefficient is lower than reported in previous studies (Van der Veer et al., 2006; Mazurié et al., in prep.). It was anticipated that the half-saturation coefficient could change as a response to low seston conditions, since this may be sitespecific and/or related to food quality (Kooijman, 2006; Pouvreau et al., 2006). There is a good match between simulated and observed ingestion rates at food concentrations

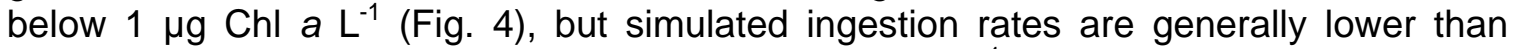

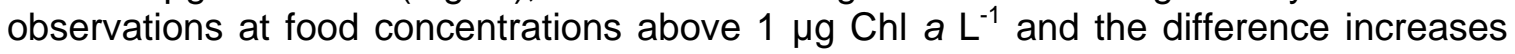
with food concentrations. The observations seem to follow a linear trajectory for ingestion rate (i.e. a Holling-I functional response), which would imply a different relationship between ingestion rate and food concentrations. A Holling-I functional response was tested in some initial pilot simulations (not presented here) and caused a stronger growth signal at higher food concentrations. This resulted in a better fit between simulations and observations at peaked $\mathrm{Chl}$ a concentrations and improved the simulations for the Flødevigen dataset. However, since the Holling-I function also worsened the fit with other datasets this path was not pursued further here.

The mismatch between simulated and observed growth at Flødevigen (dataset 7) is probably due to an incomplete representation of the ingestion processes. Autocalibration of the half-saturation coefficient $\left(X_{K}\right)$ and the maintenance rate $\left(\left[\alpha_{1}\right]\right)$ at Flødevigen resulted in extreme values with little biological realism. This could indicate that there are some features of this dataset that the model is unable to frame. Differences in $X_{K}$ values have been documented in other studies dealing with the calibration of DEB parameters. Pouvreau et al. (2006) found a range of 3.5-17 $\mu \mathrm{g} \mathrm{Chl} \mathrm{a}$ 
$\mathrm{L}^{-1}$ for oysters grown in different experimental and field conditions while, for the same species in New Zealand, Ren and Schiel (2008) found values between 1 and $1.9 \mu \mathrm{g} \mathrm{Chl}$ $a \mathrm{~L}^{-1}$. Within the same cultivated area, Bacher and Gangnery (2006) introduced some variability in $X_{K}$ to better account for spatial and inter-individual variability in oyster growth. Several reasons can be invoked to explain the need for a site-specific calibration of $X_{K}$ or more refinement of the functional response. Previous studies have demonstrated that phytoplankton composition can have significant effect on food assimilation and growth of mussels (Wang and Fisher, 1996; Ren and Ross, 2005; Ren et al., 2006). One of the distinct characteristics of the Flødevigen dataset is the frequent shifts in the Chl a concentrations, which may also indicate phytoplankton successions and shifting species composition. This may have implications for the edible fraction as well as the energetic content of the phytoplankton along the season. Cloern et al. (1995) reviewed a lot of experimental works that showed a variation of the Carbon:Chl a content between 10 and $300 \mathrm{~g} \mathrm{C} \mathrm{g} \mathrm{Chl} \mathrm{a}^{-1}$. They established that the Carbon:Chl a ratio depends on environmental factors (e.g. temperature, light, nutrient concentration) and is related to the growth rate of phytoplankton populations. Chl a may also underestimate the true food concentrations available to mussels, since heterotrophic plankton have been reported to constitute an important dietary sources for blue mussels (Davenport et al., 2000; Lehane and Davenport, 2002; Lehane and Davenport, 2004; Trottet et al., in press). Pouvreau et al. (2006), who also refer to the variability of the Carbon:Chl a ratio, proposed to use another food quantifier, e.g. total volume of phytoplankton or total amount of carbon. This variability is also discussed by Ren and Schiel (2008), who argued that temporal and spatial variations of this ratio can vary between 25 and $500 \mathrm{~g}$ $\mathrm{C} \mathrm{g} \mathrm{Chl} \mathrm{a}^{-1}$ in many bivalve farming ecosystems due to variable light limitations for instance. On this basis, Grangeré et al. (in press) improved the growth simulation of oyster growth by coupling the DEB model to an ecosystem model, using Cloern's equation (Cloern et al., 1995), to simulate the phytoplankton-carbon concentration.

The average ratio between the concentrations $\left(\mathrm{mg} \mathrm{L}^{-1}\right)$ of particulate organic carbon (POC) and Chl a for Flødevigen was $173 \mathrm{mg} \mathrm{POC} \mathrm{mg}^{-1} \mathrm{Chl}$ a, while for dataset 1 from the the Austevoll experiment it was $340 \mathrm{mg} \mathrm{POC} \mathrm{mg}^{-1} \mathrm{Chl} \mathrm{a}$. Thus, the use of $\mathrm{Chl} \mathrm{a}$ instead of POC does not seem to explain the low growth simulations compared to the observations in Flødevigen.

Food concentration within long lines can also be modified by the interactions between bivalves and phytoplankton. Food depletion has been reported in ecosystem with low current velocity and high densities of bivalve (Heasman et al., 1998; Bacher et al., 2003; Grant et al., 2008). Though depletion effect is supported by experimental work (Fréchette and Bacher, 1998; Alunno-Bruscia et al., 2000), the effect of mussel density on food availability is not clearly demonstrated in rearing structure as long lines. For instance, Lauzon-Guay et al. (2006) considered that growth, in terms of shell length, of mussels reared on longlines is density-independent over a wide range of mussel densities and that competition for space is more likely to control mussel growth than competition for food. In Norwegian fjords, food depletion has been measured within farms (Strohmeier et al., 2005, 2008) where reduction in current velocity due to friction from the long line culture has been identified as a limiting factor of food supply and mussel growth (Aure et al., 2007b). However, since modelled shell growth is lower than observed in Flødevigen, these effects from farm structure can not explain the discrepancies between model and observations in Flødevigen.

Differences in functional response are also discussed with respect to adaptation of bivalves to environmental conditions (Barillé et al., 2000; Honkoop et al., 2002). Ren and 
Schiel (2008) list a series of studies implying that variation in both genetics and environmental conditions can affect physiological rates of an organism. Pouvreau et al. (2006) discussed the possibility that plasticity in ingestion capacity could partly explain the differences in $X_{K}$ values and cause variability in other DEB parameters. However, as explained by Ren and Schiel (2008), such a factor would only play a role when mussel populations come from different ecosystems and eventually have time to adapt to local conditions. This effect is, however, little likely in these data since the mussel populations are based on local stocks.

\section{Conclusion}

From applications of DEB models to various bivalve species and different environmental conditions, there is growing evidence that this type of model is consistent with measured growth and physiological characteristics. Using the same modelling framework brings us a step forward in the understanding response of bivalves to environmental differences, but is also helps to identify gaps and lines of future work. In our study, we have pointed out that some experimental food conditions yielded starvation, which should result in changes in pathways of energy. This was manifested in our results which demonstrated a limitation of the model to simulate growth under long term starvation, and the model should be elaborated to somehow account for shrinking of structural components during prolonged starvation.

We also identified differences in growth patterns of mussel grown in different ecosystems. A possible explanation that we want to explore further is related to phytoplankton composition which could modify the feeding response of mussels. We will therefore compare several ecosystems in terms of phytoplankton species and mussel growth, using the half saturation coefficient in the mussel functional response as an indicator.

\section{Acknowledgements}

This project was funded by the Research Council of Norway (project no 173537) within the strategic institute program Carrying Capacity in Norwegian Aquaculture (CANO, http://www.imr.no/cano/start) at the Institute of Marine Research in Bergen, Norway. This project has been supported also through a bilateral AURORA grant (2008-2009) by the Norwegian Research Council and the French Ministry for Foreign Affairs. We would like to thank two anonymous referees for their helpful comments on the manuscript

\section{References}

Alunno-Bruscia, M., Petraitis, P., Bourget, E., Fréchette, M., 2000. Body-size density relationship for Mytilus edulis in an experimental food-regulated situation. Oikos $90,28-$ 42.

Aure, J., Strand, Ø., Erga, S.R. and Strohmeier, T., 2007a. Primary production enhancement by artificial upwelling in a western Norwegian fjord. Mar. Ecol. Prog. Ser. $352,39-52$.

Aure, J., Strohmeier, T. and Strand, Ø., 2007b. Modelling current speed and carrying capacity in long-line blue mussel (Mytilus edulis) farms. Aquaculture Res. 38, 304-312. 
Bacher, C. and Gangnery, A., 2006. Use of dynamic energy budget and individual based models to simulate the dynamics of cultivated oyster populations. J. Sea Res. 56, 140155.

Bacher, C. , Grant, J., Hawkins, A.J.H, Fang, J., Zhu, M., Besnard, M., 2003. Modelling the effect of food depletion on scallop growth in Sungo Bay (China). Aquat. Living Resour. 16, 10-24.

Barillé, L., Héral, M. and Barillé-Boyer, A.L., 1997. Modélisation de l'écophysiologie de l'huître creuse Crassostrea gigas dans un environnement estuarien. Aquat. Living Resour. 10, 31-48.

Barillé, L., Haure, J., Cognie, B., Leroy, A. 2000. Variations in pallial organs and eulatero-frontal cirri in response to high particulate matter concentrations in the oyster Crassostrea gigas. Can. J. Fish. Aquat. Sci. 57, 837-843.

Blanco, J., Zapata, M., and Moroño, A. 1996. Some aspects of the water flow through mussel rafts. Scientia Marina. 60, 275-282.

Bourlès, Y., Alunno-Bruscia, M., Pouvreau, S., Tollu, G., Leguay, D., Arnaud, C., Goulletquer, P., Kooijman, S.A.L.M., submitted. Modelling growth and reproduction of the Pacific oyster Crassostrea gigas: advances in the oyster-DEB model through application to a coastal pond. J. Sea Res. (Special Issue "The AquaDEB project").

Cloern, J.E., Grenz, C. and Vidergar-Lucas, L., 1995. An Empirical Model of the Phytoplankton Chlorophyll: Carbon ratio-the conversion factor between productivity and growth rate. Limnol. Oceanogr. 40, 1313-1321.

Conover, R.J. and Corner, E.D.S., 1968. Respiration and nitrogen excretion by some marine zooplankton in relation to their life cycles. Journal of the Marine Biological Association U. K., 48, 49-75.

Davenport, J., Smith, R. and Packer, M., 2000. Mussels Mytilus edulis: significant consumers and destroyers of mesozooplankton. Mar. Ecol. Prog. Ser. 198, 131-137.

Downing, W. L. , Downing, J. A. 1993. Molluscan shell growth and loss. Nature 362, 506506.

Erga, S.R., 1989. Ecological-studies on the phytoplankton of Boknafjorden, western Norway .2. Environmental-control of photosynthesis. J. Plankton Res. 11, 785-812.

Erga, S.R. et al., 2005. UV transmission in Norwegian marine waters: controlling factors and possible effects on primary production and vertical distribution of phytoplankton. Mar. Ecol. Prog. Ser. 305, 79-100.

Figueiras, F.G., Labarta, U. and Reiriz, M.J.F., 2002. Coastal upwelling, primary production and mussel growth in the Rias Baixas of Galicia. Hydrobiologia 484, 121-131. Fréchette, M., Butman, C.A. and Geyer, W.R., 1989. The importance of boundary-layer flow processes in supplying phytoplankton to the benthic suspension-feeder, Mytilus edulis. Limnol. Oceanogr. 34, 19-36.

Fréchette, M., Bacher, C., 1998. A modelling study of optimal stocking density of mussel populations kept in experimental tanks. J. Exp. Mar. Biol. Ecol. 219, 241-255.

Frette, Ø., Erga, S.R., Hamre, B., Aure, J. and Stamnes, J.J., 2004. Seasonal variability in inherent optical properties in a western Norwegian fjord. Sarsia 89, 276-291.

Gangnery, A., Chabirand, J.-M., Lagarde, F., Le Gall, P., Oheix, J., Bacher, C., Buestel, D., 2003. Growth model of the Pacific oyster, Crassostrea gigas, cultured in Thau Lagoon (Mediterranée, France). Aquaculture 215, 267-290.

Gnaiger, E. and Forstner, H., 1983. Polarographic oxygen sensors: aquatic and physiological applications. Springer, Berlin, XII, 370 pp.

Grangeré, K., Ménesguen, A., Lefebvre, S., Bacher, C., Pouvreau, S., accepted. Modelling the influence of environmental factors on year-to-year variability of the physiological status of the Pacific oyster Crassostrea gigas in an estuarine embayment: the Baie des Veys (France). (Special Issue "The AquaDEB project"). 
Grant, J. and Bacher, C., 1998. Comparative models of mussel bioenergetics and their validation at field culture sites. J. Exp. Mar. Biol. Ecol. 219, 21-44.

Grant, J., Bacher, C., Cranford, P.J., Guyondet, T., Carreau, M., 2008. A spatially explicit ecosystem model of seston depletion in dense mussel culture. J. Mar. Systems. 73, 155-168.

Hawkins, A.J.S., Duarte, P., Fang, J.G., Pascoe, P.L., Zhang, J.H., Zhang, X.L., Zhu, M.Y., 2002. A functional model of responsive suspension-feeding and growth in bivalve shellfish, configured and validated for the scallop Chlamys farreri during culture in China. J. Exp. Mar. Biol. Ecol. 281, 13-40.

Heasman, K.G., Pitcher, G. C., McQuaid, C. D., Hetcht, T., 1998. Shellfish mariculture in the Benguela system: raft culture of Mytilus galloprovincialis and the effect of rope spacing on food extraction, growth rate, production, and condition of mussels. J. Shellfish Res. 17, 33-39.

Honkoop, P.J.C., Bayne, B.L., Drent, J. 2002. Flexibility of size of gills and palps in the Sidney rock oyster Saccostrea glomerata (Gould, 1850) and the Pacific oyster Crassostrea gigas (Thunberg, 1793). J. Exp. Mar. Biol. Ecol. 282, 113-133.

Karayücel, S. and Karayücel, İ., 2000. The effect of environmental factors, depth and position on the growth and mortality of raft-cultured blue mussels (Mytilus edulis). Aquaculture Res. 31, 893-899.

Kooijman, S.A.L.M., 1986. Energy budgets can explain body size relations. J. Theoretical Biol., 121: 269-282.

Kooijman, S.A.L.M., 2006. Pseudo-faeces production in bivalves. J. Sea Res. 56, 103106.

Kooijman, S.A.L.M., 2000. Dynamic energy and mass budgets in biological systems. Cambridge University Press, Cambridge, 419 pp.

Lauzon-Guay, J.S., Barbeau, M.A., Watmough, J., Hamilton, D.J., 2006. Model for growth and survival of mussels Mytilus edulis reared in Prince Edward Island, Canada. Mar. Ecol. Prog. Ser. 323, 171-183.

Lehane, C. and Davenport, J., 2002. Ingestion of mesozooplankton by three species of bivalve; Mytilus edulis, Cerastoderma edule and Aequipecten opercularis. J. Mar. Biol. Assoc. UK, 82, 615-619.

Lehane, C. and Davenport, J., 2004. Ingestion of bivalve larvae by Mytilus edulis: experimental and field demonstrations of larviphagy in farmed blue mussels. Mar. Biol. 145, 101-107.

Mallet, A.L. and Carver, C.E., 1993. Temporal production patterns in various size groups of the blue mussel. J. Exp. Mar. Biol. Ecol. 170, 75-89.

Mazurié, J., Thomas Y., Bouget, J.F., Pouvreau, S., Alunno-Bruscia, M., Gohin, F., Saulquin, B., Struski, C., Bacher' C. In prep. Modelling the growth and reproduction of Mytilus edulis (L.) in Mont Saint-Michel bay from 2003 to 2006, with a Dynamic Energy Budget model.

Palmer, R.E. and Williams, L.G., 1980. Effect of particle concentration on filtration efficiency of the Bay scallop Argopecten irradians and the oyster Crassostrea virginica. Ophelia 19, 163-174.

Pitcher, G.C. and Calder, D., 1998. Shellfish mariculture in the Benguela system: Phytoplankton and the availability of food for commercial mussel farms in Saldanha Bay, South Africa. J. Shellfish Res. 17, 15-24.

Platt, T. and Irwin, B., 1973. Caloric content of phytoplankton. Limnol. Oceanogr. 18, 306-310.

Pouvreau, S., Bourles, Y., Lefebvre, S., Gangnery, A. and Alunno-Bruscia, M., 2006. Application of a dynamic energy budget model to the Pacific oyster, Crassostrea gigas, reared under various environmental conditions. J. Sea Res. 56, 156-167. 
Paasche, E. and Erga, S.R., 1988. Phosphorus and nitrogen limitation of phytoplankton in the inner Oslofjord (Norway). Sarsia 73, 229-243.

Ren, J.S. and Ross, A.H., 2001. A dynamic energy budget model of the Pacific oyster Crassostrea gigas. Ecol. Model. 142, 105-120.

Ren, J.S. and Ross, A.H., 2005. Environmental influence on mussel growth: A dynamic energy budget model and its application to the greenshell mussel Perna canaliculus. Ecol. Mod. 189, 347-362.

Ren, J.S., Ross, A.H. and Hayden, B.J., 2006. Comparison of assimilation efficiency on diets of nine phytoplankton species of the greenshell mussel Perna canaliculus. J. Shellfish Res. 25, 887-892.

Ren, J.S. and Schiel, D.R., 2008. A dynamic energy budget model: parameterisation and application to the Pacific oyster Crassostrea gigas in New Zealand waters. J. Exp. Mar. Biol. Ecol. 361, 42-48.

Ross, A.H. and Nisbet, R.M., 1990. Dynamic models of growth and reproduction of the mussel Mytilus edulis L. Funct. Ecol. 4, 777-787.

Scholten, H. and Smaal, A.C., 1998. Responses of Mytilus edulis L. to varying food concentrations: testing EMMY, an ecophysiological model. J. Exp. Mar. Biol. Ecol. 219, 217-239.

Smaal, A.C. and Widdows, J., 1994. The scope for growth of bivalves as an integrated response parameter in biological monitoring. In: K. K. (Ed.), Biomonitoring of Coastal Waters and Estuaries. CRC Press, Boca Raton, pp. 247-268.

Smaal, A.C. and Vonck, A., 1997. Seasonal variation in C, N and P budgets and tissue composition of the mussel Mytilus edulis. Mar. Ecol. Prog. Ser. 153, 167-179.

Strickland, J.D.H. and Parson, T.R. 1972. A practical handbook of seawater analysis. $2^{\text {nd }}$ ed. J. Fish. Res. Board Canada 167.

Strohmeier, T., Aure, J., Duinker, A., Castberg, T., Svardal, A., Strand, Ø., 2005. Flow reduction, seston depletion, meat content and distribution of diarrhetic shellfish toxins in a long-line blue mussel (Mytilus edulis) farm. J. Shellfish Res. 24, 15-23.

Strohmeier, T., Duinker, A., Strand, $\varnothing$. and Aure, J., 2008. Temporal and spatial variation in food availability and meat ratio in a longline mussel farm (Mytilus edulis). Aquaculture 276, 83-90.

Strohmeier , T., Strand, $\varnothing$. and Cranford, P., subm. Clearance rates of the great scallop (Pecten maximus) and blue mussel (Mytilus edulis) at low seston concentrations. Mar. Biol.

Trottet, A., Roy, S., Tamigneaux, E., Lovejoy, C. and Réjean, T., in press. Impact of suspended mussels (Mytilus edulis L.) on plankton communities in a Magdalen Islands lagoon (Québec, Canada): A mesocosm approach. J. Exp. Mar. Biol. Ecol.

van der Meer, J., 2006. An introduction to Dynamic Energy Budget (DEB) models with special emphasis on parameter estimation. J. Sea Res. 56, 85-102.

van der Veer, H.W., Cardoso, J. and van der Meer, J., 2006. The estimation of DEB parameters for various Northeast Atlantic bivalve species. J. Sea Res. 56, 107-124.

van Haren, R.J.F. and Kooijman, S.A.L.M., 1993. Application of a Dynamic Energy Budget model to Mytilus edulis (L.). Neth. J. Sea Res. 31, 119-133.

Wang, W.X. and Fisher, N.S., 1996. Assimilation of trace elements and carbon by the mussel Mytilus edulis: Effects of food composition. Limnol. Oceanogr. 41, 197-207.

Wei, H., Sun, J., Moll, A. and Zhao, L., 2004. Phytoplankton dynamics in the Bohai Sea observations and modelling. J. Mar. Syst. 44, 233-251.

Whyte, J.N.C., Englar, J.R., Carswell, B.L., 1990. Biochemical-composition and energy content of 6 species of phytoplankton used in mariculture of bivalves. Aquaculture 60, 231-241. 


\section{Tables}

Table 1. The DEB-parameters for Mytilus edulis. The columns: "Value" refers to parameter values obtained from other studies; "Estimated" refers to parameter values estimated in this study, and "Calibrated" refers to parameter values calibrated in this study. The calibrated parameter values for datasets 4 and 7 were omitted from the table due to their extreme values. The estimated parameters were corrected for the Arrhenius temperature using $273 \mathrm{~K}\left(20^{\circ} \mathrm{C}\right)$ as the reference temperature $\left(T_{1}\right)$. The parameter values marked in bold constitute the basic parameter set of this study.

\begin{tabular}{|c|c|c|c|c|c|c|}
\hline Parameters & Symbo & Unit & $\begin{array}{l}\text { Valu } \\
\text { e }\end{array}$ & Reference & Estimated & $\begin{array}{l}\text { Calibrate } \\
\text { d }\end{array}$ \\
\hline \multicolumn{7}{|l|}{ Primary parameters: } \\
\hline Assimilation efficiency & $\kappa_{A}$ & - & 0.75 & $\begin{array}{l}\text { Van der Veer et al. } \\
(2006\end{array}$ & & \\
\hline $\begin{array}{l}\text { Fraction of } p_{c} \text { to maintenance and } \\
\text { growth }\end{array}$ & $\kappa$ & - & 0.45 & Mazurié et al. (in prep) & & \\
\hline Half-saturation coefficient & $x_{K}$ & $\mu_{1} \mathrm{~g} \mathrm{Chl} \mathrm{a} \mathrm{L^{- }}$ & 1.77 & Mazurié et al. (in prep) & $\begin{array}{l}1.29(0.85- \\
2.65)\end{array}$ & $\begin{array}{l}1.03- \\
1.72\end{array}$ \\
\hline Max. surf. area-specific ingestion rate & $\left\{\mathbb{R}_{X m}\right\}$ & $\mathrm{J} \mathrm{cm}^{-2} \mathrm{~d}^{-1}$ & 273 & Mazurié et al. (in prep) & & $222-330$ \\
\hline Maximum storage density & {$\left[E_{m}\right]$} & $\mathrm{J} \mathrm{cm}^{-3}$ & 2190 & $\begin{array}{l}\text { Van der Veer et al. } \\
(2006)\end{array}$ & & \\
\hline Shape coefficient & $\delta_{V}$ & - & 0.26 & Mazurié et al. (in prep) & $0.231 \pm 0.003$ & \\
\hline Structural volume at sexual maturity & $V_{p}$ & $\mathrm{~cm}^{3}$ & 0.06 & $\begin{array}{l}\text { Van der Veer et al. } \\
(2006)\end{array}$ & & \\
\hline Volume-specific costs for structure & {$\left[E_{G}\right]$} & $\mathrm{J} \mathrm{cm}^{-3}$ & 1900 & $\begin{array}{l}\text { Van der Veer et al. } \\
(2006)\end{array}$ & & \\
\hline Volume-specific maintenance costs & {$\left[\mathbb{R}_{M}\right]$} & $\mathrm{J} \mathrm{cm}^{-3} \mathrm{~d}^{-1}$ & 24 & $\begin{array}{l}\text { Van der Veer et al. } \\
(2006)\end{array}$ & $27.8 \pm 3.3$ & $\begin{array}{l}24.9- \\
32.3\end{array}$ \\
\hline \multicolumn{7}{|l|}{ Additional parameters: } \\
\hline Arrhenius temperature & $T_{A}$ & - & 5800 & $\begin{array}{l}\text { Van der Veer et al. } \\
(2006)\end{array}$ & & \\
\hline Lower boundary of tolerance range & $T_{L}$ & $\mathrm{~K}$ & 275 & $\begin{array}{l}\text { Van der Veer et al. } \\
(2006)\end{array}$ & & \\
\hline Rate of decrease at lower boundary & $T_{A L}$ & $\mathrm{~K}$ & $\begin{array}{l}4543 \\
0\end{array}$ & $\begin{array}{l}\text { Van der Veer et al. } \\
(2006)\end{array}$ & & \\
\hline Rate of decrease at upper boundary & $T_{A H}$ & $\mathrm{~K}$ & $\begin{array}{l}3137 \\
6\end{array}$ & $\begin{array}{l}\text { Van der Veer et al. } \\
(2006)\end{array}$ & & \\
\hline Reference temperature & $T_{1}$ & $\mathrm{~K}$ & 293 & $\begin{array}{l}\text { Van der Veer et al. } \\
(2006)\end{array}$ & & \\
\hline Upper boundary of tolerance range & $T_{H}$ & $\mathrm{~K}$ & 296 & $\begin{array}{l}\text { Van der Veer et al. } \\
(2006)\end{array}$ & & \\
\hline
\end{tabular}


Table 2. Deviations (\%, calculated from equation 11) between model simulations and observations for each dataset and for all datasets combined (pooled data). Rows 1-5 show deviations for simulations using different parameter sets: Basic parameter set (includes parameters estimated from experiments); Literature (based entirely on values from Van der Veer et al. (2006) and Mazurié et al. (in prep.)), $X_{K}$ (calibrated value for half saturation coefficient), [ $\left.{ }_{4}\right]$ (calibrated value for maintenance rate), $\left\{\alpha_{m}\right\}$ (calibrated value for maximum energy ingestion rate). The two last rows show the effect of initial allocation to reproduction only and reserves only.

\begin{tabular}{|c|c|c|c|c|c|c|c|c|}
\hline \multirow[t]{3}{*}{ Parameter } & \multicolumn{8}{|c|}{ Datasets } \\
\hline & 1 & 2 & 3 & 4 & 5 & 6 & 7 & $1-7$ \\
\hline & Exp.tr. 1 & Exp.tr. 2 & Exp.tr. 3 & Exp.tr. 4 & Toskasundet & Austevoll & Flødevigen & Pooled data \\
\hline Basic parameters & 9.6 & 8.8 & 10.9 & 25.6 & 6.9 & 5.6 & 35.5 & 14.7 \\
\hline Literature & 14.6 & 12.8 & 14.3 & 18.8 & 13.5 & 19.5 & 53.2 & 20.9 \\
\hline$X_{K}$ & 8.5 & 5.9 & 7.4 & 5.5 & 6.5 & 5.6 & 13.6 & 14.7 \\
\hline$\left[P_{M}\right]$ & 8.3 & 5.6 & 7.5 & 6.5 & 6.7 & 5.6 & 17.3 & 14.3 \\
\hline & 8.6 & 6.0 & 7.4 & 7.9 & 6.3 & 5.6 & 13.5 & 14.7 \\
\hline Reproduction only & 9.6 & 8.6 & 11.1 & 25.9 & 7.7 & 13.8 & 33.0 & 15.7 \\
\hline Reserves only & 9.6 & 9.1 & 10.8 & 25.0 & 6.4 & 10.2 & 38.0 & 15.6 \\
\hline
\end{tabular}


Table 3. Parameter values obtained by auto-calibration for each dataset (1-7) and all datasets combined (pooled data). The parameters subject to calibration were: [ $\left.\&_{M}\right]$ (Volume-specific maintenance costs), $\left\{\&_{X m}\right\}$ (Maximum surface-area specific ingestion rate) and $X_{K}$. (Halfsaturation coefficient). The parameters have been corrected for the Arrhenius temperature factor, using $20^{\circ} \mathrm{C}$ as reference temperature.

\begin{tabular}{|c|c|c|c|c|c|c|c|c|}
\hline \multirow[t]{3}{*}{ Parameter } & \multicolumn{8}{|c|}{ Dataset } \\
\hline & 1 & 2 & 3 & 4 & 5 & 6 & 7 & $1-7$ \\
\hline & Exp.tr. 1 & Exp.tr. & Exp.tr. & Exp.tr. & Toskasunde & Austevoll & Flødevigen & Pooled \\
\hline$X_{k}$ & 1.57 & 1.72 & 1.03 & 0.04 & 1.55 & 1.30 & 0.29 & 1.31 \\
\hline [1] & 32.2 & 32.3 & 24.9 & 13.4 & 28.4 & 28.1 & 0.2 & 24.9 \\
\hline$\left\{\mathbb{R}_{X m}\right\}$ & 237 & 222 & 330 & 7593 & 242 & 271 & 411 & 273 \\
\hline
\end{tabular}

Table 4. Model sensitivity $(S)$ to changes in the half-saturation coefficient $\left(X_{K}\right)$ and the somatic maintenance rate $\left(\left[\left[_{1}\right]\right)\right.$. The parameters were changed within the standard deviations of the estimates (see Table 1). $S$ scales changes in model predictions relative to changes in the parameter value according to equation (12), and sensitivity is classified according to Wei et al. (2004): insensitive $(S<0.1)$, sensitive $(0.1<S<0.4)$ and more sensitive (S>0.4).

\begin{tabular}{lrrrrrrrr}
\hline Parameter & \multicolumn{8}{c}{ Dataset } \\
& 1 & 2 & 3 & 4 & 5 & 6 & 7 & $1-7$ \\
& Exp.tr. & Exp.tr. 2 & Exp.tr. 3 & Exp.tr. 4 & Toskasundet & Austevoll & Flødevigen & Pooled \\
\hline $\mathrm{S}\left(X_{K}=0.85\right)$ & 0.27 & 0.22 & 0.22 & 0.01 & 0.29 & 0.34 & 0.48 & 0.26 \\
$\mathrm{~S}\left(X_{K}=2.65\right)$ & 0.11 & 0.09 & 0.08 & 0.01 & 0.12 & 0.14 & 0.22 & 0.11 \\
$\mathrm{~S}\left(\left[\left[_{M}\right]=24.5\right)\right.$ & 0.26 & 0.26 & 0.44 & 0.96 & 0.33 & 0.33 & 0.37 & 0.42 \\
$\left.\mathrm{~S}\left([]_{M}\right]=31.1\right)$ & 0.24 & 0.25 & 0.46 & 1.02 & 0.27 & 0.27 & 0.33 & 0.40 \\
\hline
\end{tabular}




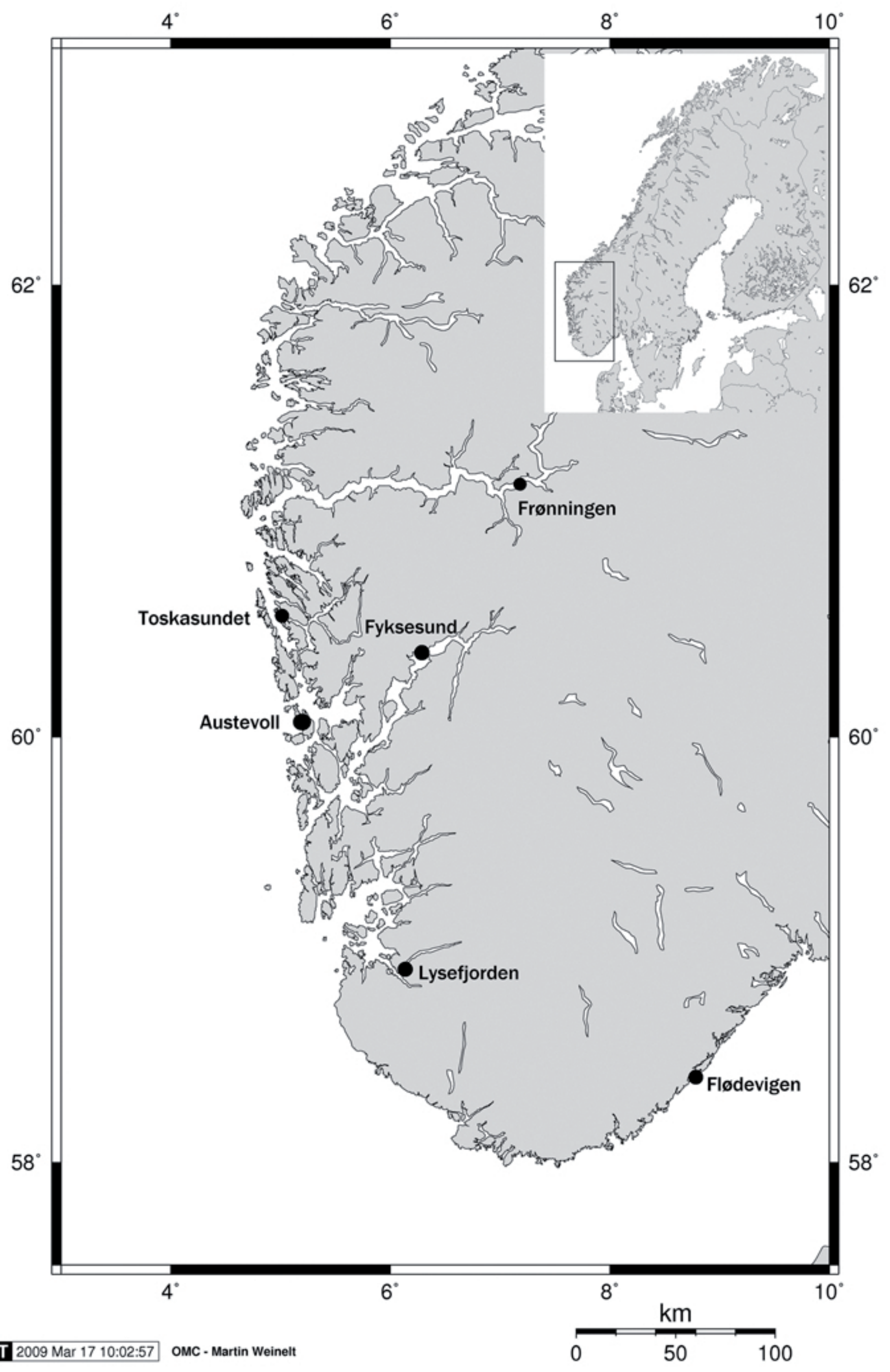



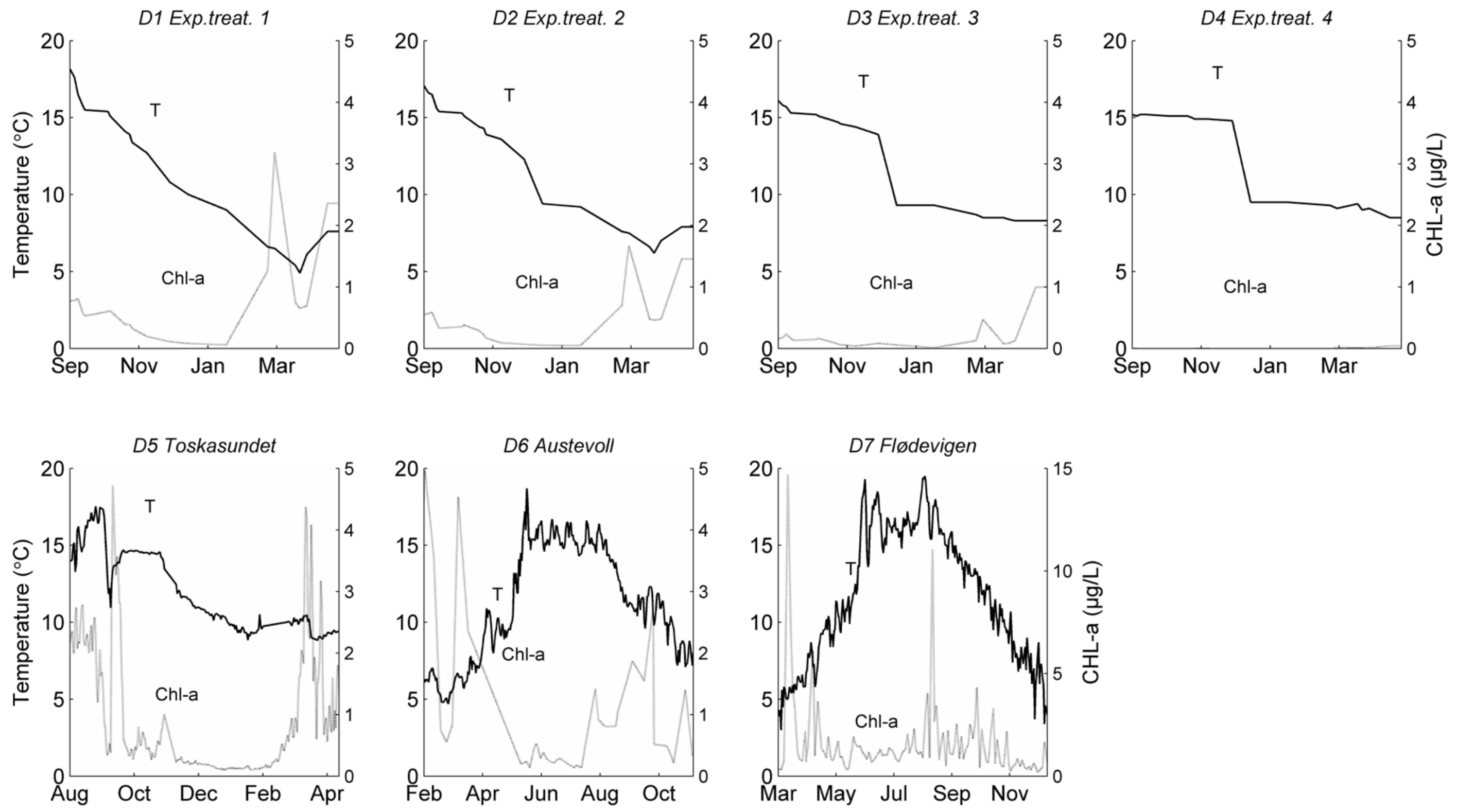


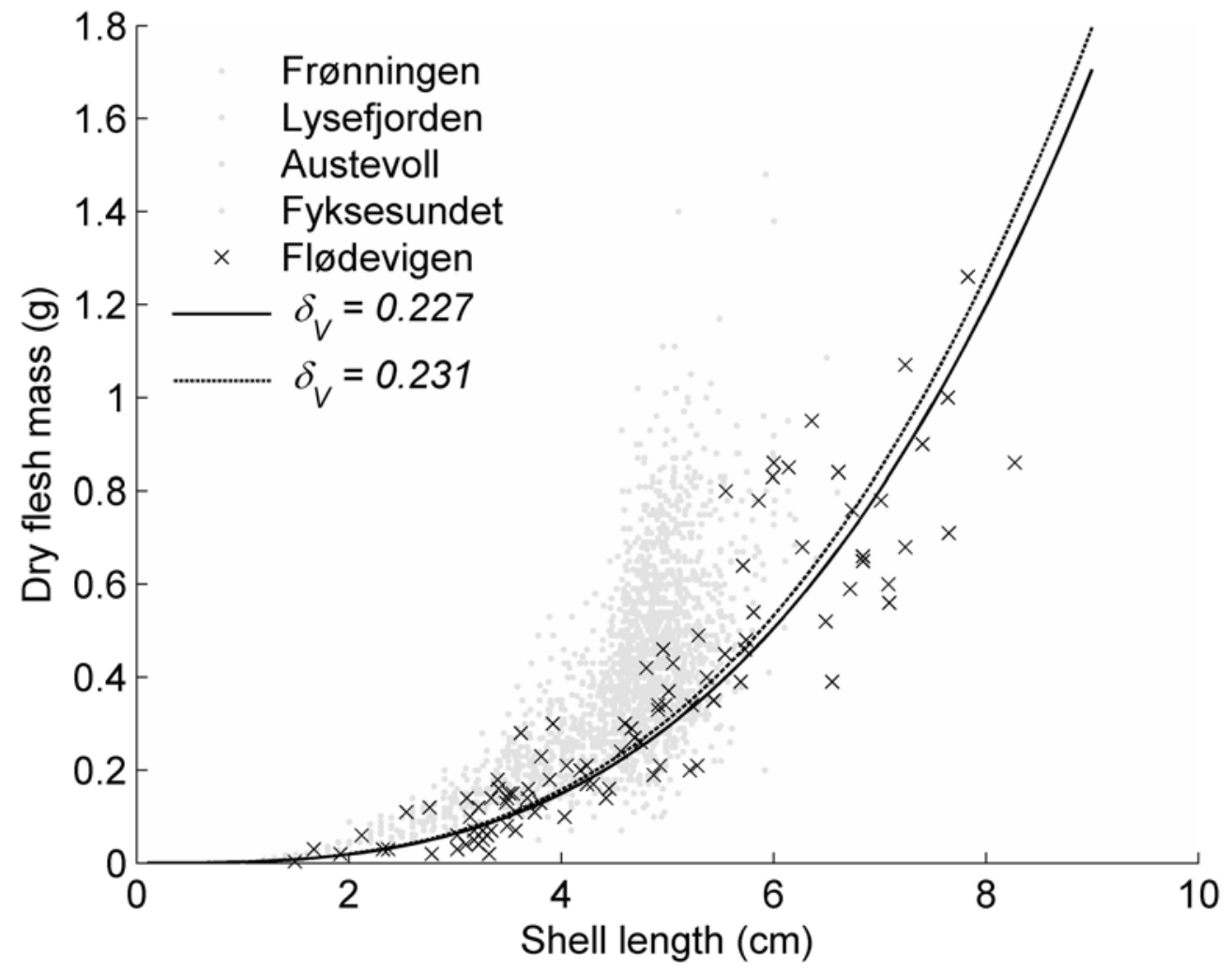




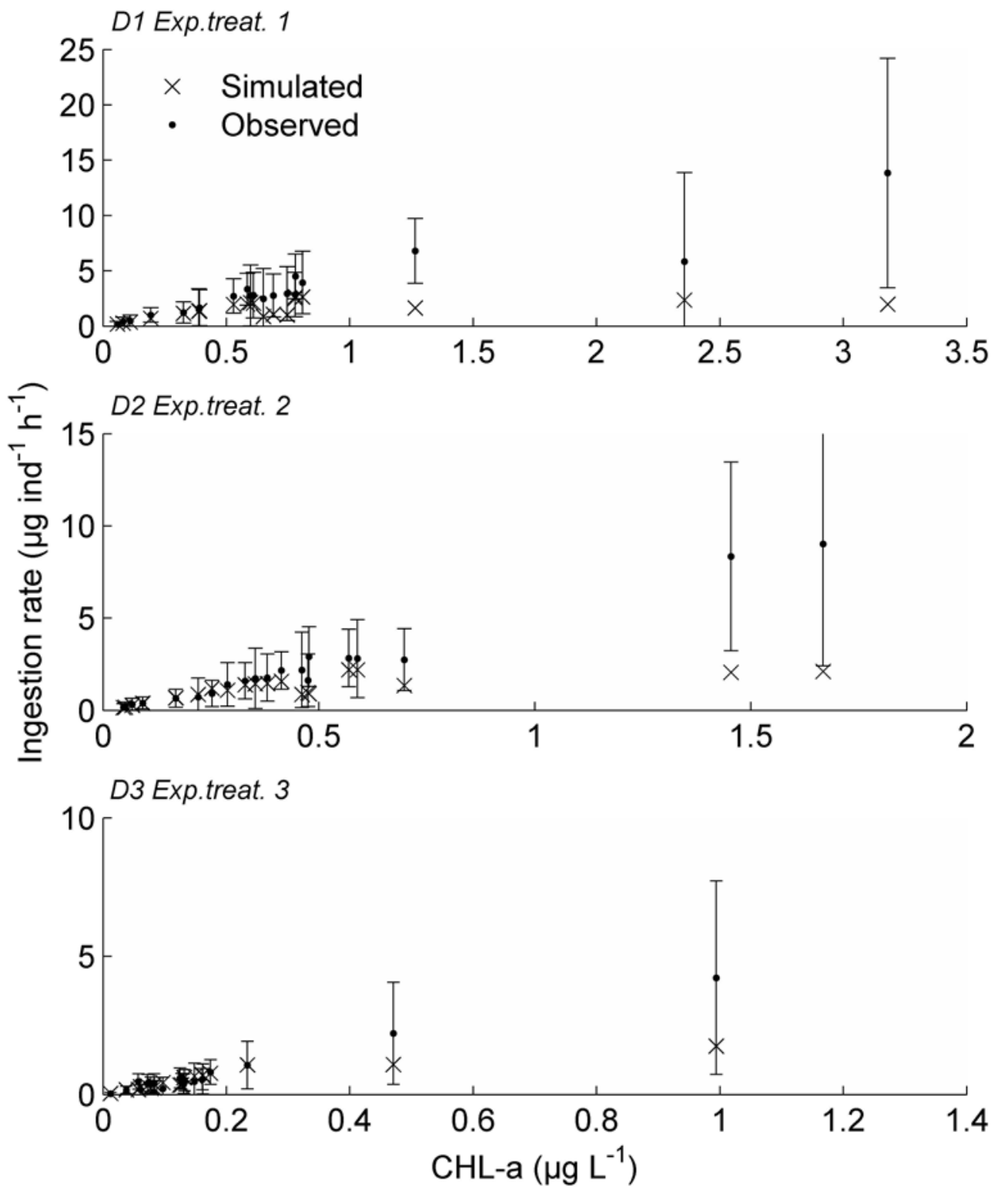



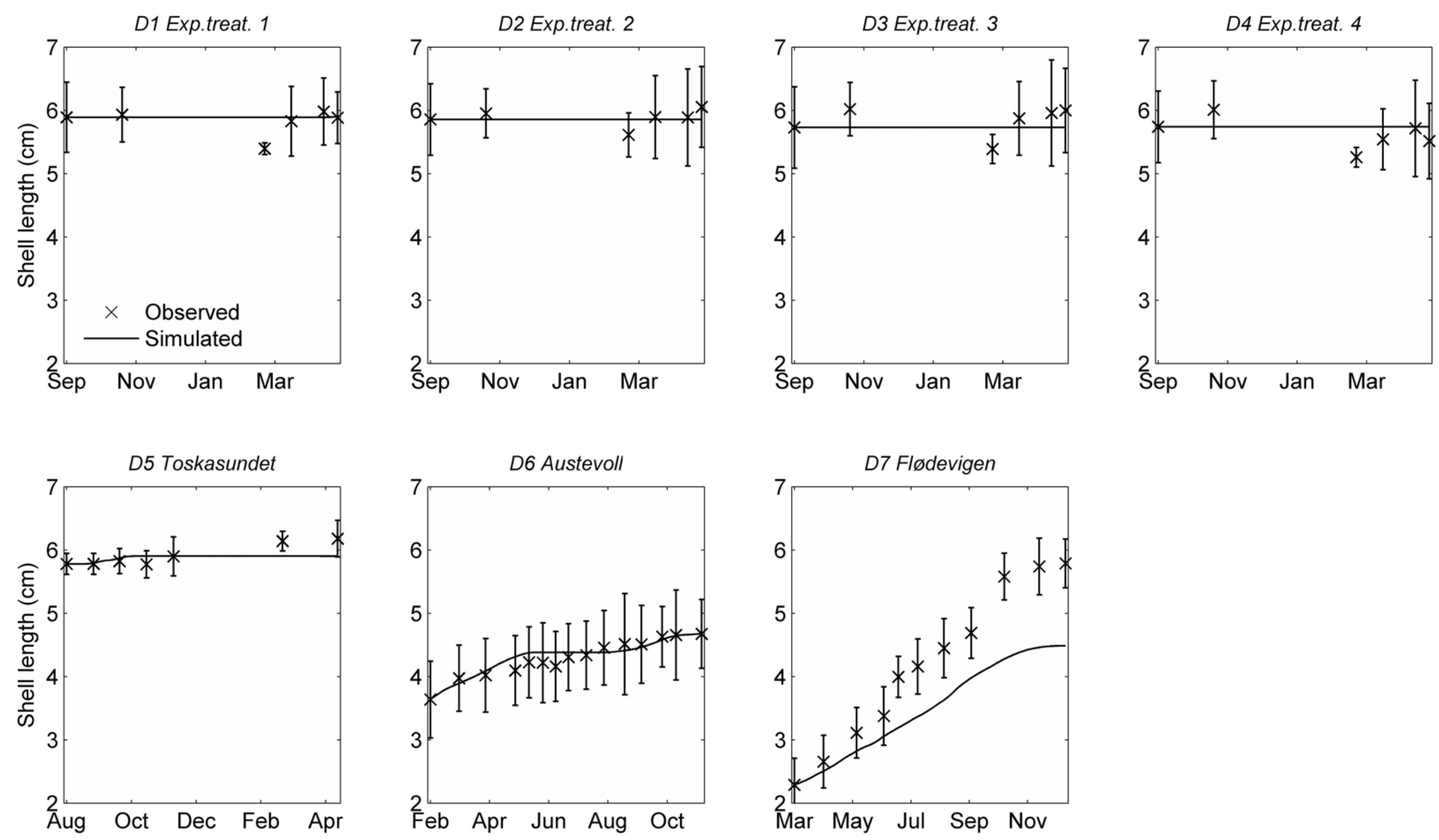

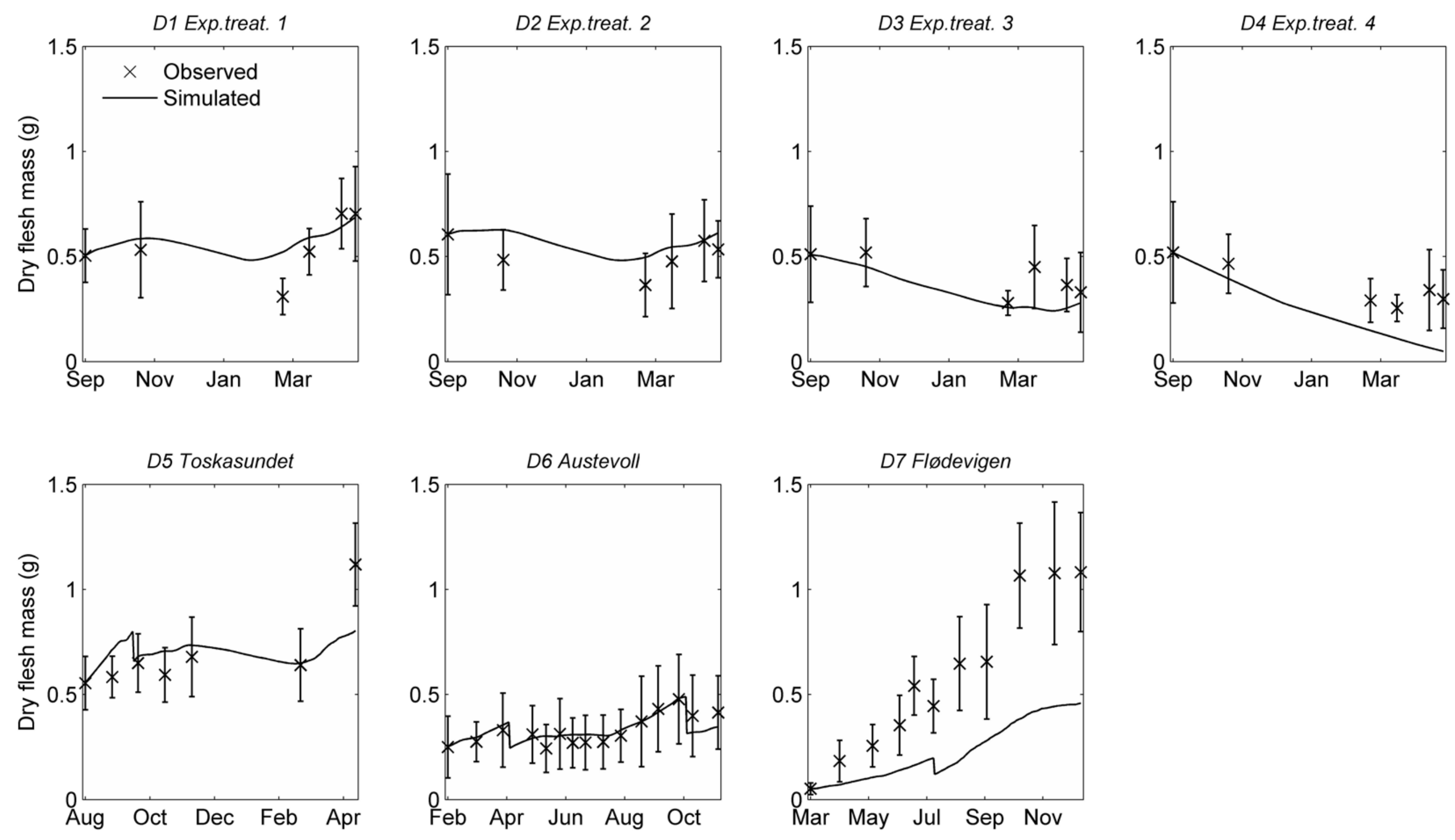

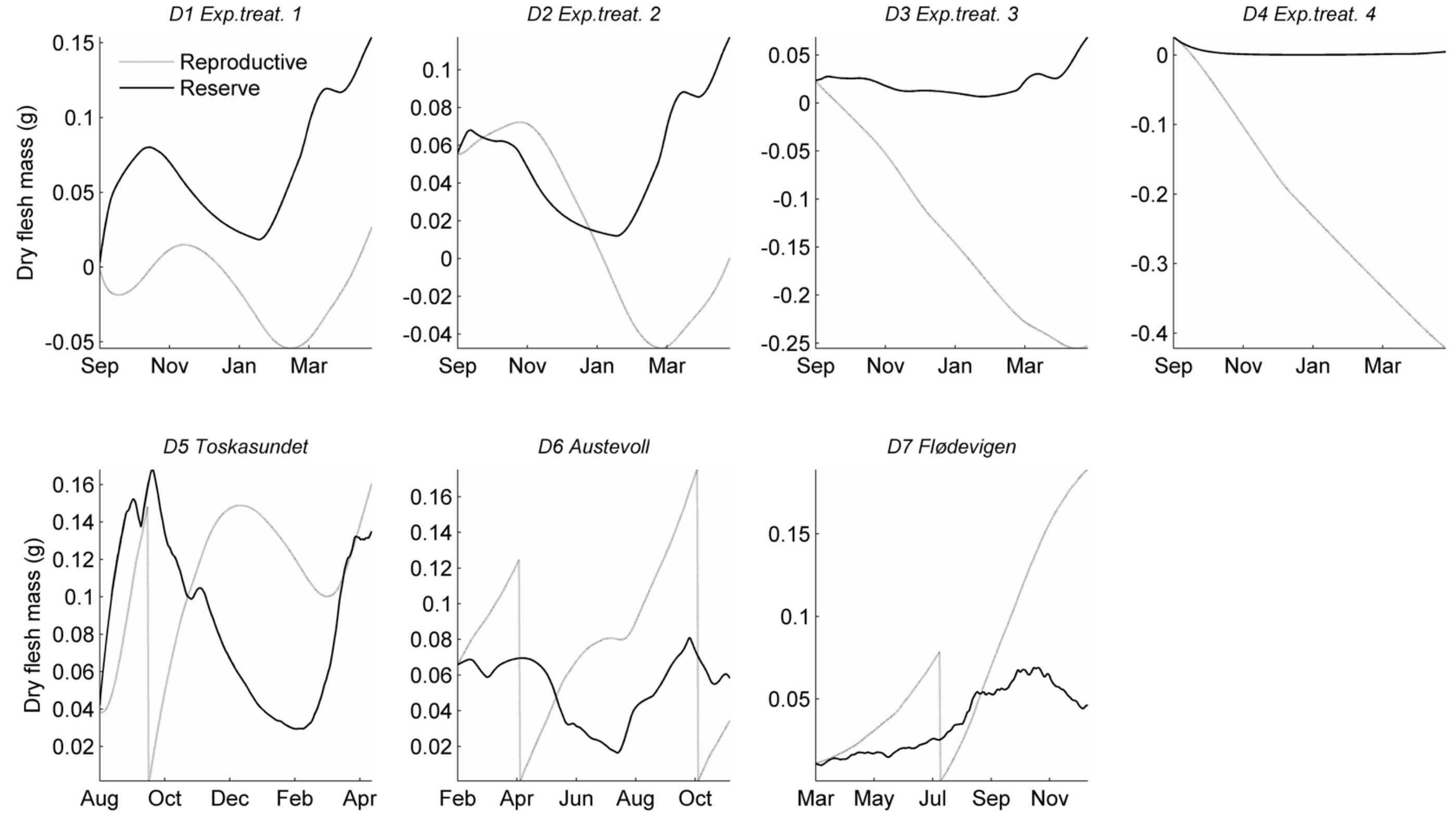

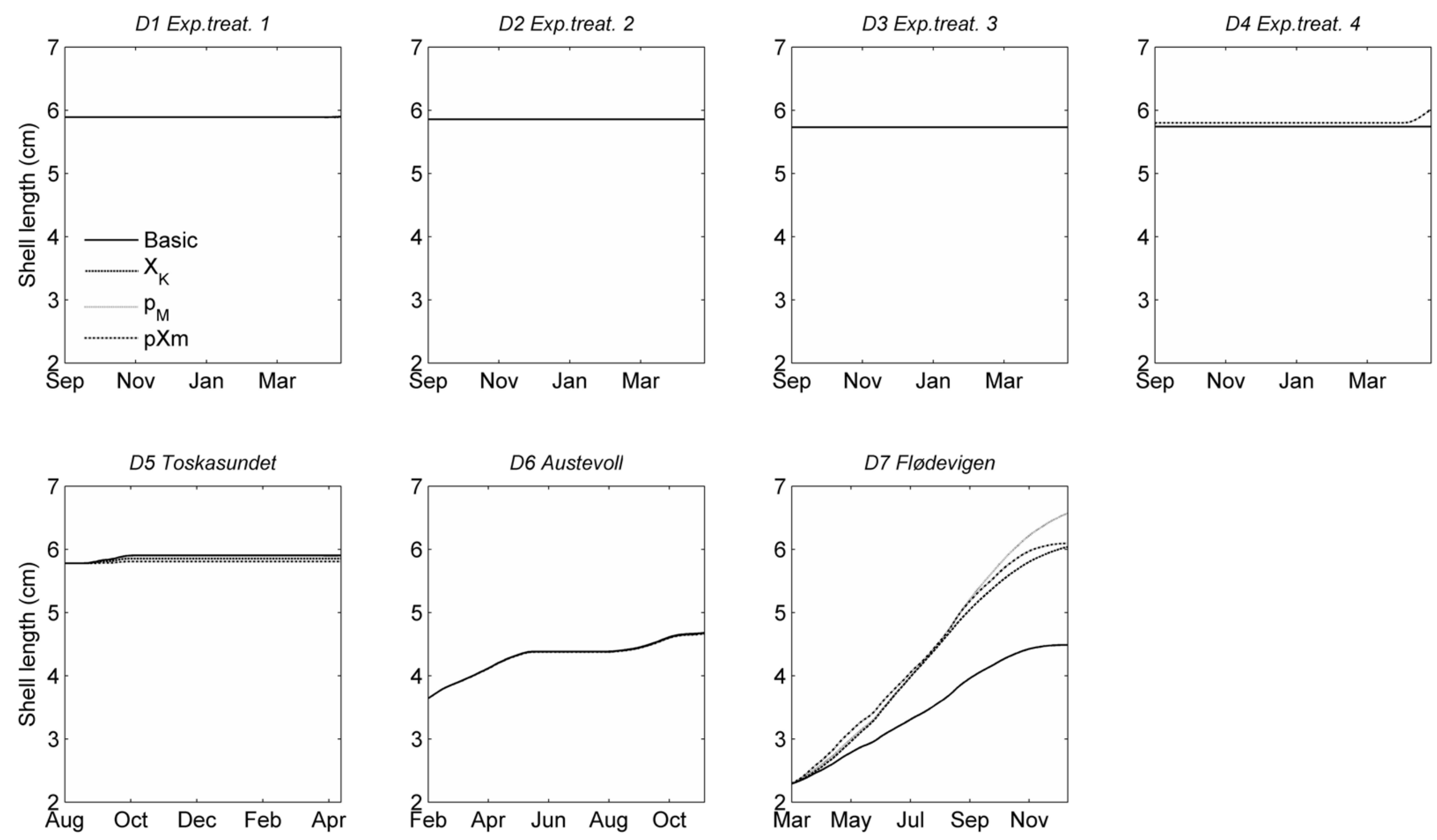

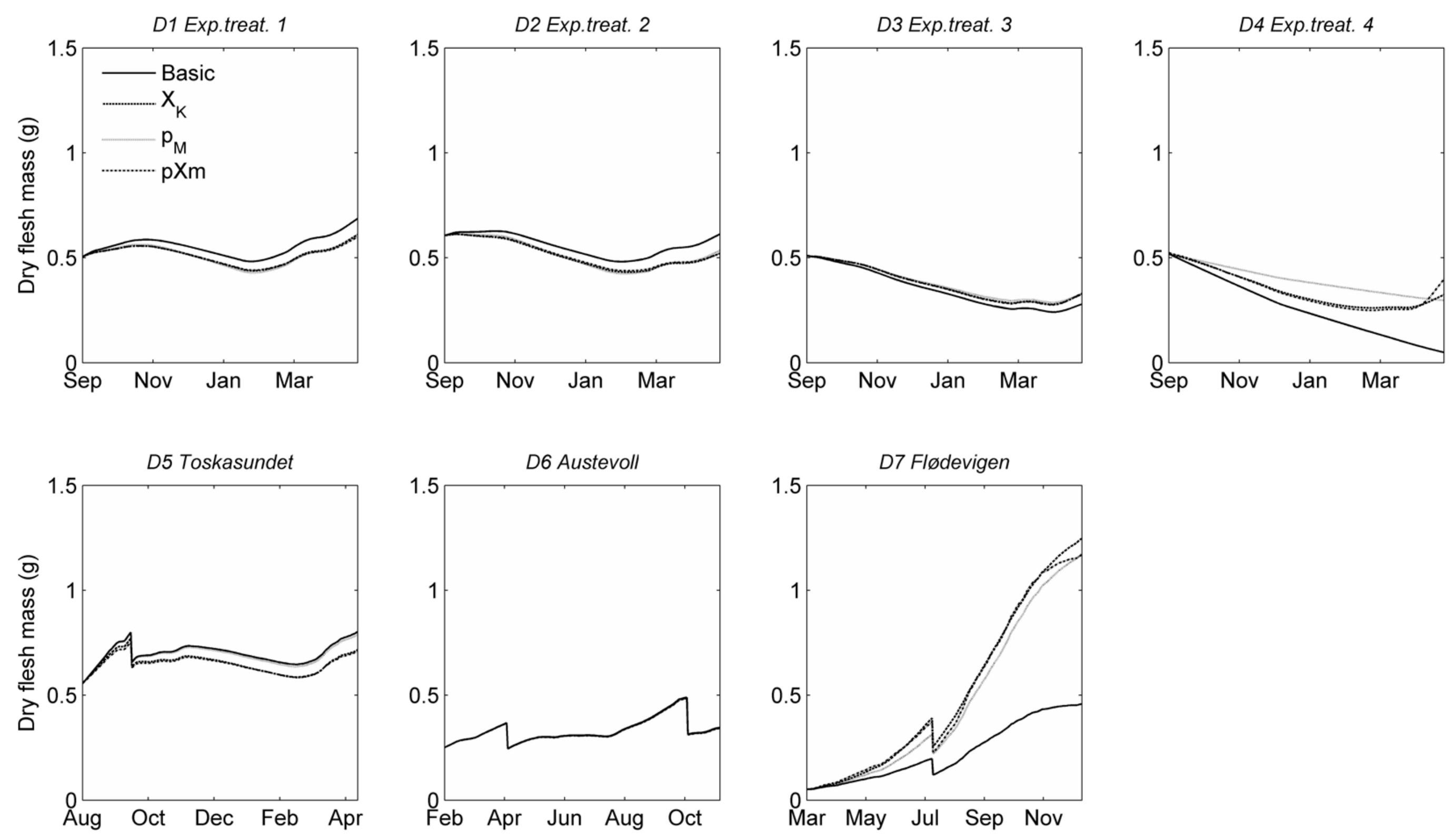

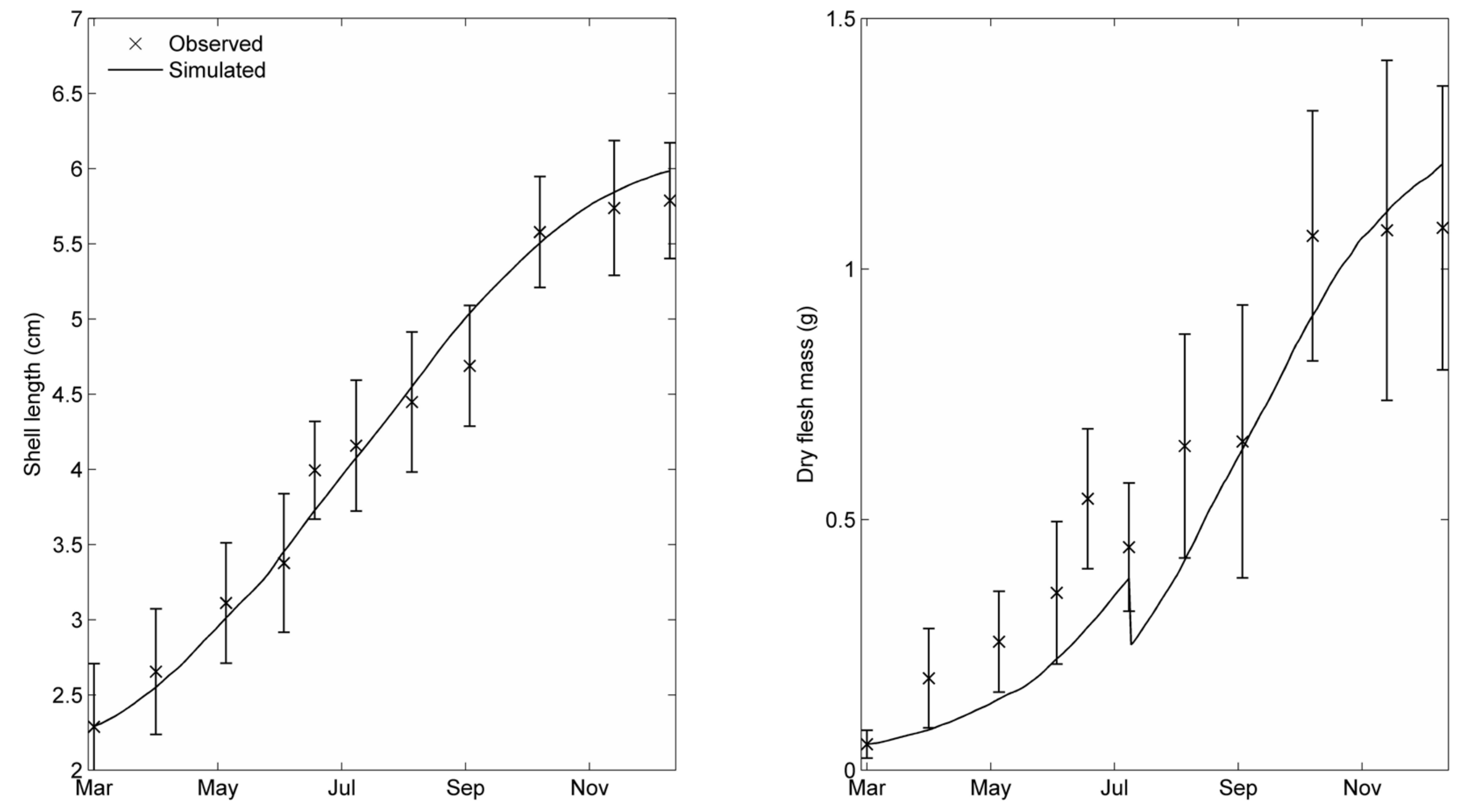